Department of Microbiology

University of Helsinki

Finland

\title{
LOW ANTIBIOTIC \\ CONCENTRATIONS AND \\ RESISTANCE IN MICROBIAL \\ COMMUNITIES
}

JOHANNES CAIRNS

\section{ACADEMIC DISSERTATION}

To be presented, with the permission of the Faculty of Agriculture and Forestry of the University of Helsinki, for public examination in auditorium B2 (A109), Viikki B Building, Latokartanonkaari 7, on

August 10th, 2018, at 12 o'clock noon. 
SUPERVISORS

- Docent Teppo Hiltunen

Department of Microbiology

University of Helsinki, FINLAND

- Docent Marko Virta

Department of Microbiology

University of Helsinki, FINLAND

PRE-EXAMINERS

- Professor Dan I. Andersson

Department of Medical Biochemistry and Microbiology

Uppsala University, SWEDEN

- Dr. Álvaro San Millán

Department of Microbiology

Hospital Universitario Ramón y Cajal (IRYCIS), SPAIN

THESIS COMMITTEE

- Professor Kaarina Sivonen

Department of Microbiology

University of Helsinki, FINLAND

- Docent Sari Timonen

Department of Microbiology

University of Helsinki, FINLAND

OPPONENT

- Dr. Pauline Scanlan

School of Microbiology

University College Cork, IRELAND

CUSTOS

- Professor Kaarina Sivonen

Department of Microbiology

University of Helsinki, FINLAND

ISSN 2342-5423 (print)

ISSN 2342-5431 (online)

ISBN 978-951-51-4370-9 (paperback)

ISBN 978-951-51-4371-6 (PDF)

Dissertationes Schola Doctoralis Scientiae Circumiectalis, Alimentariae, Biologicae

Cover image: Depiction of dynamic selective environment of bacteria, which are killed by antibiotics, ingested by protozoan predators and lysed by bacteriophages.

Illustration by Veera Partanen.

Layout by Kata Naaranoja @ No Jam Studio

http://ethesis.helsinki.fi

Unigrafia

Helsinki 2018 



\section{ce}

SOLVING THE ANTIBIOTIC CRISIS REQUIRES A RIGOROUS UNDERSTANDING OF THE ORIGINS, DIVERSITY, AND EVOLUTIONARY FORCES THAT DRIVE THE ESTABLISHMENT AND MOBILITY OF RESISTANCE GENES

\section{3}

-Gerry Wright, ISME16 conference, Montreal, Canada 


\section{TABLE OF CONTENTS}

List of original publications IV

Author contribution IV

Abbreviations $\quad V$

Glossary $\quad v$

Abstract VIII

Tiivistelmä $\quad$ IX

Acknowledgements $\quad x$

$1 \quad$ Introduction 1

1.1 Antibiotics and their occurrence at subinhibitory concentrations 1

1.2 Antibiotic resistance evolution 4

1.2.1 Adaptive resistance 7

$\begin{array}{ll}\text { 1.2.2 } & \text { Acquired resistance } \\ & 13\end{array}$

1.3 Antibiotics and resistance in microbial communities 24

2 Aims of the thesis 28

3 Summary of material and methods 29

$4 \quad$ Summary of results and discussion 31

4.1 Adaptive mutations under species interactions $(1,11) \quad 31$

4.2 Plasmid transfer under species interactions (III, IV) 34

4.3 Community composition under low concentrations (IV) 37

$5 \quad$ Conclusions and prospects 39

References 40 


\section{LIST OF ORIGINAL PUBLICATIONS}

This thesis is based on the following publications:

I. Cairns, J., Becks, L., Jalasvuori, M. \& Hiltunen, T. Sublethal streptomycin concentrations and lytic bacteriophage together promote resistance evolution. Philosophical Transactions of the Royal Society B: Biological Sciences 372, 20160040, doi: 10.1098/rstb.2016.0040 (2017).

II. Cairns, J., Frickel, J., Jalasvuori, M., Hiltunen, T. \& Becks, L. Genomic evolution of bacterial populations under coselection by antibiotics and phage. Molecular Ecology 26, 1848-1859, doi: 10.1111/mec.13950 (2017).

III. Cairns, J., Jalasvuori, M., Ojala, V., Brockhurst, M. \& Hiltunen, T. Conjugation is necessary for a bacterial plasmid to survive under protozoan predation. Biology Letters 12, 20150953, doi: 10.1098/rsbl.2015.0953 (2016).

IV. Cairns, J., Ruokolainen, L., Hultman, J., Tamminen, M., Virta, M. \& Hiltunen, T. Ecology determines how low antibiotic concentration impacts community composition and horizontal transfer of resistance genes. Communications Biology 1,35, doi: 10.1038/s42003-018-0041-7 (2018).

The publications are referred to in the text by their roman numerals.

\section{AUTHOR CONTRIBUTION}

I. Johannes Cairns participated in the design of the study and the experimental work, performed the data analysis, and wrote the first article draft.

II. Johannes Cairns participated in the design of the study, performed most of the bioinformatics and statistical analysis, and wrote the first article draft.

III. Johannes Cairns participated in the design of the study, performed most of the experimental work and data analysis, and wrote the first article draft.

IV. Johannes Cairns designed the study together with Teppo Hiltunen, performed the experimental work and bioinformatics analysis, and wrote the first article draft. 


\section{ABBREVIATIONS}

AR

ARG

CP

CNV

epicPCR

HGT

INDEL

ICE

MGE

MBC

MIC

MMR

Mpf

MSC

Phage

SNP

WGS
Antibiotic resistance or resistant

Antibiotic resistance gene

Coupling protein

Copy-number variation

Emulsion, paired isolation and concatenation PCR

Horizontal gene transfer

Insertion or deletion

Integrative and conjugative element

Mobile genetic element

Minimum bactericidal concentration

Minimum inhibitory concentration

Methyl-directed mismatch repair system

Mating pair formation

Minimum selective concentration

Bacteriophage

Single-nucleotide polymorphism

Whole-genome sequencing 


\section{Clonal interference}

Competition between lineages with different adaptive mutations, interfering with the strength and directionality of selection. Clonal interference is caused by the inability of adaptive mutations to recombine into the same genome in asexually reproducing organisms, such as bacteria.

\section{Conjugation}

Transfer of DNA from donor to recipient cell through a type IV secretion system comprising a mating pair formation (Mpf) complex and the coupling protein (CP). Mpf components (protein complex and pilus) establish physical contact with a recipient cell and create a secretion pore. The CP delivers the DNA to pore entry and potentially partakes in secretion.

\section{Ecological interactions}

Important ecological interactions include competition, predation and parasitism. The major predators of bacteria are protozoa, which are unicellular eukaryotes, and the major parasites are bacteriophages, which are viruses that infect bacteria.

\section{Emulsion, paired isolation and concaten-} tion PCR (epicPCR)

A culture-independent method for detection of the presence of two DNA regions in the same cell in a heterogeneous sample. Individual cells are trapped in polyacrylamide beads. Linker primer PCR is used to amplify two DNA regions into a fusion product. After nested PCR, the fragment is sequenced. When one region is a phylogenetic marker, epicPCR allows detection of the phylogenetic distribution of a gene of interest.

\section{Epistasis}

The fitness effect of a locus is altered by the presence of another locus. In positive and negative epistasis, two mutations in combination produce higher or lower fitness, respectively, than the sum of counterparts. In sign epistasis, the sign of a mutation (fitness-beneficial/-negative) changes.

\section{Evolutionary forces}

Drift, natural selection, mutation, recombina- 
tion and gene flow. Mutation, recombination and gene flow create genetic (allelic) variability in a population of an organism. In bacteria, recombination and gene flow mainly occur through horizontal gene transfer. Drift and selection act on the variability, determining the change in allele frequency over time. Drift denotes random change in allele frequency, and its effect is inversely proportional to population size. Selection denotes non-random change in allele frequency. Selection can be positive, where the frequency of an adaptive allele increases over time, or negative (i.e. purifying), where the frequency of a maladaptive allele decreases.

\section{Horizontal gene transfer (HGT)}

Transfer of DNA between cells, which can represent the same or different species. HGT mechanisms include conjugation, transduction (HGT via bacteriophages), transformation (direct uptake of environmental DNA), and transfer via membrane vesicles.

\section{Methyl-directed mismatch repair system (MMR)}

A post-replicative DNA error correction mechanism. The proteins MutS, MutH and MutL coordinate binding to and excision of the daughter strand at the site of a DNA mismatch, followed by repair by DNA Polymerase III.

\section{Minimum inhibitory concentration (MIC)}

The minimum antibiotic concentration inhibiting visible growth of a bacterial population in vitro under a specified cultivation protocol.

\section{Minimum selective concentration (MSC)}

The antibiotic concentration where antibiotic resistant and susceptible genotypes have equal fitness, and drift and natural selection equally determine the fate of antibiotic resistance. At concentrations exceeding the MSC, which is usually lower than the MIC, the antibiotic resistant genotype can be subject to positive selection.

\section{Mobile genetic element (MGE)}

Genetic element that shows mobility within or between genetic elements or cells. MGEs include plasmids, integrative and conjugative el- ements, bacteriophages, transposable elements and integrons. Environmental DNA can also be considered an MGE.

\section{Negative frequency dependent selection}

The fitness of a species or genotype increases with decreasing frequency, which can be caused e.g. by cross-feeding interactions, parasitism and predation. This is an example of balancing selection maintaining species coexistence.

\section{Niche differentiation}

Resource use or spatial separation of members in a community, reducing competitive interactions and enabling coexistence.

\section{Plasmid}

An independently replicating extrachromosomal, usually circular DNA molecule. Often encodes beneficial traits, such as antibiotic resistance, and conjugative machinery allowing horizontal transfer between cells.

\section{Pleiotropy}

A gene influences more than one phenotypic trait.

\section{Protozoa}

An informal term used to refer to unicellular eukaryotes that feed on organic matter, which can include bacteria (bacterivory).

\section{Single-nucleotide polymorphism (SNP)}

A point mutation in a bacterial genome compared to ancestral reference genome, including single-base substitutions, insertions and deletions.

\section{SOS response}

The presence of single-stranded DNA in a cell indicative of cellular damage leads to a global change in gene regulation, including recruitment of low-fidelity DNA polymerases. This allows replication over damaged DNA and increases mutation rate.

\section{Species diversity}

The number (richness) and similarity in abundance (evenness) of species in a community, and the number of taxonomic groups they represent. 


\section{ABSTRACT}

Antibiotics often occur in different environments at concentrations insufficient to inhibit the growth of susceptible bacteria. Subinhibitory concentrations can, nevertheless, select for chromosomal antibiotic resistance mutations and mobile genetic elements carrying antibiotic resistance genes, such as conjugative plasmids. However, it has been unclear whether this occurs in typical natural habitats where bacteria live in multispecies communities and interact with viral and protozoan consumers. In such settings, similar selection can also occur on other bacterial traits, potentially interfering with antibiotic resistance evolution.

In this thesis, the combined effect of low antibiotic concentrations and ecological interactions on antibiotic resistance evolution was investigated. The thesis consists of four studies. In the first and second study, antibiotic and bacteriophage resistance evolution was examined at the phenotypic or whole-genome level when a bacterial population was exposed to one versus both factors. In the third study, the effect of antibiotics and protozoan predation on the spread and maintenance of a conjugative antibiotic resistance plasmid in a bacterial population was determined. The fourth study examined the effect of a low antibiotic concentration, protozoan predation, and spatial layout of habitat on community composition and horizontal transfer of a conjugative plasmid in a multispecies bacterial community.

Antibiotic resistance evolution was shown to be promoted by low antibiotic concentrations independent of the presence of ecological interactions. The presence of protozoan predation also promoted the spread and maintenance of a resistance plasmid even in the absence of antibiotics. This demonstrates that ecological factors other than antibiotics can also play a role in the horizontal transfer of antibiotic resistance genes. Moreover, a low antibiotic concentration altered bacterial community composition, diversity, and the strains that received a resistance plasmid, although predation and spatial layout of habitat were equally strong or stronger drivers. Since the community effects of low antibiotic concentrations can be weaker or similar in strength to the effects of other ecological drivers, knowledge of antibiotic alone may be insufficient for predicting changes in the structure or diversity of a community. 
Antibiootteja esiintyy eri ympäristöissä usein niin alhaisina pitoisuuksina, etteivät ne estä edes niille herkkien bakteerien kasvua. Tällaisetkin pitoisuudet voivat kuitenkin tuottaa valintapainetta, jolloin antibiooteille vastustuskykyä aiheuttavat kromosomaaliset mutaatiot tai liikkuvat geneettiset elementit, kuten konjugatiiviset plasmidit, lisääntyvät bakteeripopulaatiossa. Vielä ei tiedetä, päteekö tämä bakteerien tyypillisissä elinympäristöissä, joissa bakteerit ovat osa monilajisia yhteisöjä ja vuorovaikutuksessa virusten sekä alkueläinsaalistajien kanssa. Tällaisissa olosuhteissa valintapaine voi kohdistua myös muihin bakteerin ominaisuuksiin, mikä voi häiritä antibioottiresistenssievoluutiota.

Tässä työssä tutkittiin alhaisten antibioottipitoisuuksien ja ekologisten vuorovaikutusten yhteisvaikutusta antibioottiresistenssievoluutioon. Työ koostuu neljästä osatutkimuksesta. Ensimmäisessä ja toisessa osatutkimuksessa tarkasteltiin antibiootti- ja virusresistenssin evoluutiota bakteerin ilmiasussa tai perimässä altistamalla bakteeri joko antibiootille tai virukselle tai molemmille. Kolmannessa osatutkimuksessa tarkasteltiin antibiootin ja alkueläinsaalistuksen vaikutusta konjugatiivisen antibioottiresistenssiplasmidin leviämiseen ja säilymiseen bakteeripopulaatiossa. Neljännessä osatutkimuksessa tarkasteltiin alhaisen antibioottipitoisuuden, alkueläinsaalistuksen ja avaruudellisen rakenteen vaikutusta yhteisörakenteeseen sekä konjugatiivisen plasmidin leviämiseen monilajisessa bakteeriyhteisössä.

Tutkimuksessa havaittiin, että alhaiset antibioottipitoisuudet lisäsivät antibioottiresistenssiä bakteeripopulaatiossa myös ekologisten vuorovaikutusten alaisuudessa. Lisäksi alkueläinsaalistus edisti resistenssiplasmidin leviämistä ja säilymistä bakteeripopulaatiossa antibiootista riippumatta. Tämä osoittaa, että myös muut ekologiset tekijät kuin antibiootit voivat olla merkityksellisiä antibioottiresistenssigeenien liikkuvuuden kannalta. Monilajisessa bakteeriyhteisössä matala antibioottipitoisuus muutti yhteisön rakennetta, monimuotoisuutta ja plasmidin vastaanottavia kantoja. Myös alkueläinsaalistus ja avaruudellinen rakenne muuttivat näitä tekijöitä vähintään yhtä voimakkaasti. Koska matalan antibioottipitoisuuden vaikutus yhteisöön voi olla samaa suuruusluokkaa tai pienempi kuin keskeisten ekologisten tekijöiden, tieto pelkästään antibiootista ei välttämättä riitä ennustamaan muutosta yhteisön koostumuksessa tai monimuotoisuudessa. 


\section{ACKNOWLEDGEMENTS}


$\mathrm{T}$ his work was carried out at the Department of Microbiology, University of Helsinki, Finland. This doctoral thesis was supported by Academy of Finland (\#106993 and \#307213) and University of Helsinki (\#490152) grants to Docent Teppo Hiltunen, and by a Finnish Cultural Foundation grant (\#160149) to the author in 2016 as well as a salaried position funded by the Doctoral Programme in Microbiology and Biotechnology, University of Helsinki, during 2017-2018.

As is almost without exception the case in science, the work in this thesis is the product of collaborative efforts. My principal supervisor Docent Teppo Hiltunen has provided me with research opportunities beyond the scope PhD students typically experience, and for that, in addition to ample ideas and hands-on supervision, I express my sincere gratitude. I am also indebted to my other supervisor Docent Marko Virta who has been open to creative collaboration beyond his molecular field of expertise, as well as providing resources and working facilities. For pre-examining my thesis, I thank Professor Dan Andersson and Dr. Álvaro San Millán, and for agreeing to act as my opponent, I thank Dr. Pauline Scanlan. I am grateful to all co-authors for fruitful collaboration, and would especially like to mention those who also acted as important mentors: Lutz Becks, Jenni Hultman, Matti Jalasvuori, Manu Tamminen and Jens Frickel.
For technical and practical assistance, I express my gratitude to Mariella Aalto-Araneda, Roosa Jokela, Mika Kalsi, Antti Karkman, Heikki Kiheri, Tuulia Mali, Jan Mattila, Johanna Muurinen, Kata Naaranoja, Iina Nieminen, Iiris Nikula, Veera Partanen, Katariina Pärnänen, Matti Ruuskanen, Lyudmila Saari, Riitta Saastamoinen, Saara Suominen, Paula Typpö, and those members of the Department of Microbiology whose name I might have forgotten to mention.

For inspiring discussions about the nature of science and knowledge, I thank Sini Ojala and Leo Aarnio, and for invigorating gym sessions, I thank Jarkko Kylmälä. I thank my family for an international and dynamic upbringing, including exposure to many conflicting viewpoints and experiences, nurturing an intellectual curiosity toward everything. Finally, I thank Aki, without whom I would not have pursued these studies or experienced so many things in life and love. 



\title{
1 INTRODUCTION
}

\subsection{Antibiotics and their occurrence at subinhibitory concentrations}

\begin{abstract}
ntibiotics are substances which, at sufficient $\mathrm{A}_{\text {concentrations, kill bacteria (bactericidal an- }}$ tibiotics) or prevent their reproduction (bacteriostatic antibiotics). They function by impairing key cellular functions such as replication, transcription, translation or cell wall synthesis. Fungi and bacteria synthesizing antibiotics are ubiquitous in nature. Phylogenetic studies suggest antibiotic synthesizing genes to have emerged over 2 billion years ago. ${ }^{1,2}$ The ecological function of antibiotics has been hypothesized to be the inhibition of competitors. ${ }^{3}$ For instance, fungi have longer generation times than bacteria, which gives bacteria a competitive advantage in nutrient uptake. Antibiotic production may therefore be a competitive strategy utilized by fungi to secure nutrients for their use. Alternatively, antibiotics have been suggested to function as signaling molecules owing to the belief that environmental concentrations (in the low ng $\mathrm{l}^{-1} \mathrm{or} \mathrm{kg}^{-1}$ when detectable) ${ }^{4-6}$ are too low to exert inhibitory effects ${ }^{7{ }^{8}}$. However, antibiotic concentrations in pristine environments are poorly understood due to precision and accuracy problems of detection methods ${ }^{4,5}$ and likely uneven concentration distributions. Therefore, the prevalence of inhibitory concentrations in natural environments remains unclear.
\end{abstract}


The discovery of antibiotics started in the early 20th century with arsphenamine (1907: Paul Ehrlich) that was synthesized chemically ${ }^{9}$ and penicillin (1928: Alexander Fleming) that was produced by the fungus Penicillium chrysogenum $^{10}$. In 1940-1960, many of the major classes of modern antibiotics were discovered, and, facilitated by the development of large-scale industrial manufacture, they revolutionized the ability of humans to treat infectious diseases that had previously been the leading cause of death (Table 1). ${ }^{11}$ Today, in addition to production by naturally occurring microbes, many antibiotics can be synthesized chemically or by genetically engineered microbes.

In 1950-1960, antibiotics were widely adopted in veterinary medicine for the treatment of bacterial infections, and in animal agriculture also for growth promotion and the control of endemic diseases. ${ }^{12}$ More antibiotics are currently used in agriculture and aquaculture than in human healthcare. ${ }^{13,14}$ Global antibiotic use in animal agriculture alone is estimated to have exceeded 63,000 tons in 2010 and to rise by $67 \%$ by $2030 .{ }^{15} \beta$-lactams are the most widely used class of antibiotics, especially in animal agriculture, having recently been reported to account for over half of total global antibiotic sales. ${ }^{16,17}$ The total use of antibiotics, the use of different antibiotic classes, and measures taken to control antibiotic use in human and animal healthcare and agriculture display strong geographic and geopolitical patterns. Antibiotic use is highest and least controlled in certain low- and middle-income countries, especially countries in Asia. ${ }^{15,18,19}$

To assess antibiotic susceptibility and dosing in human healthcare, the concept of minimum inhibitory concentration (MIC) was developed. MIC is defined as the minimum antibiotic concentration that inhibits visible growth of a bacterial population in vitro under a specified cultivation protocol. An extension of MIC, the minimum bactericidal concentration (MBC) denotes a concentration that causes a reduction of $\geq 99.9 \%$ of bacteria in an inoculum. MBC is usually the same as MIC for bactericidal antibiotics, and several-fold higher than the MIC for bacteriostatic antibiotics. ${ }^{20}$ Effective dosing of antibiotics, most frequently administered orally or intravenously, requires that serum concentrations exceed the MIC for a sufficient proportion of the dosing time interval. MIC is expressed as $\mu \mathrm{g} \mathrm{ml}^{-1}$. In other words, concentrations in the range $1-1000 \mathrm{mg} \mathrm{l}^{-1}$ are typically required for complete inhibition of the growth of susceptible bacteria. Following the dosing time interval, antibiotics occur at decreasing sub-MICs in tissues until complete elimination. The time it takes for an antibiotic to be eliminated depends on its half-life. For instance, the half-life of vancomycin is 6-12 h, such that it takes over two days to eliminate $99 \%$ of the antibiotic. ${ }^{20}$

Depending on the antibiotic class, $20-80 \%$ of ingested antibiotics are excreted by humans and animals, mainly in urine and feces. ${ }^{21}$ The excreted antibiotics subsequently end up in wastewater, sludge and manure. Although less widespread, significant industrial antibiotic pollution also occurs from production plants. ${ }^{22}$ As a consequence, antibiotic concentrations in human-impacted environments, such as agricultural and aquaculture settings and the water bodies and soils receiving wastewater treatment plant and antibiotic production plant effluents, can exceed those found in pristine environments by several orders of magnitude. In the most polluted $\operatorname{sites}^{23-25}$, concentrations can exceed $10 \mathrm{mg} \mathrm{l}^{-1}$ and $100 \mathrm{mg} \mathrm{kg}^{-1}$, and be in the $\mu \mathrm{g}^{-1}$ to $\mathrm{mg} \mathrm{l}^{-1}$ order in surrounding water bodies and soils. However, lower concentrations are reported in more commonplace scenarios. For instance, concentrations in the $1-10 \mu \mathrm{g} \mathrm{l}^{-1}$ range can occur in municipal wastewater ${ }^{26}$, although the surface waters receiving municipal wastewater are usually similar to pristine envi- 


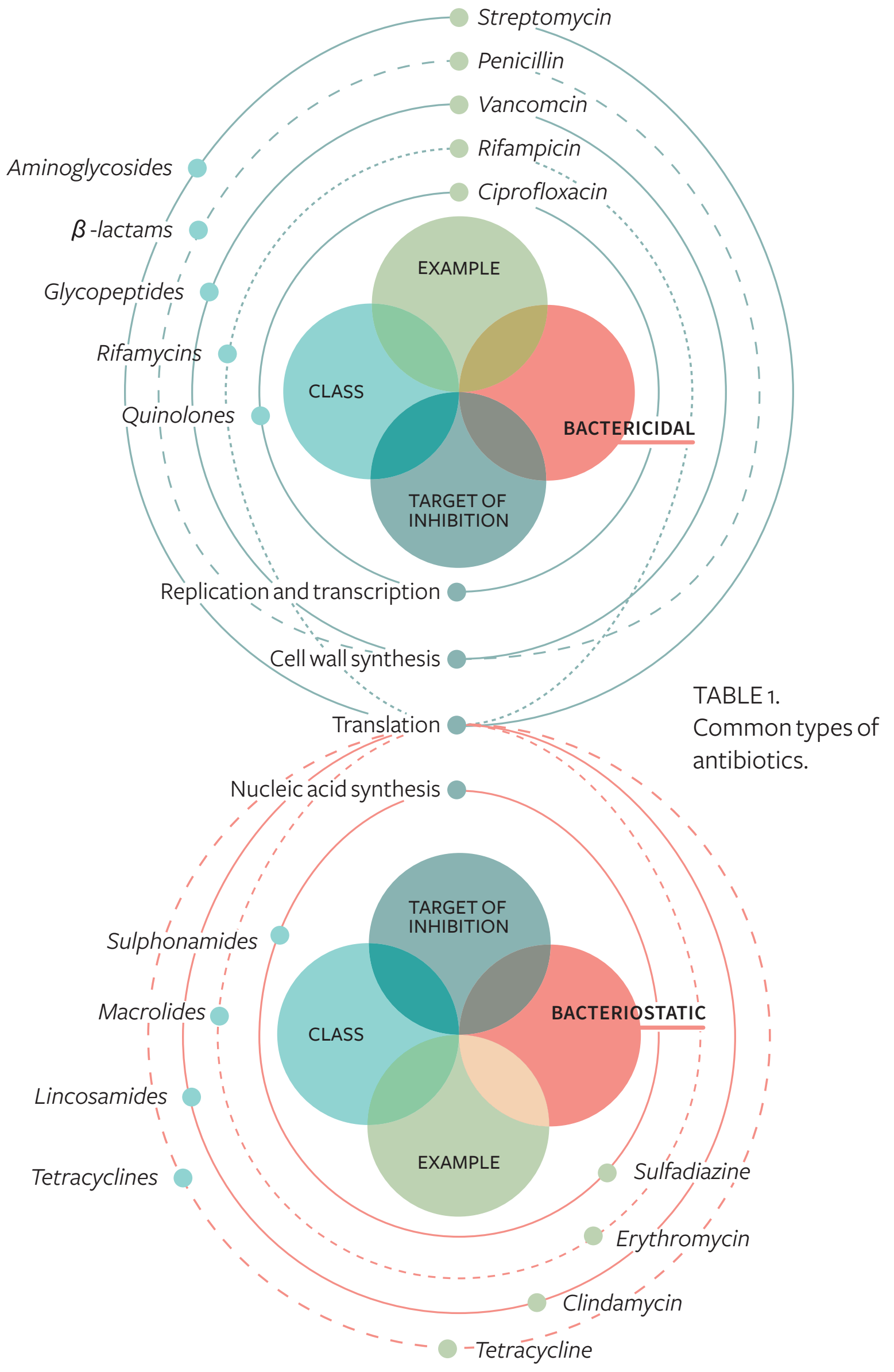


ronments, rarely exceeding $1 \mu \mathrm{g} \mathrm{l^{-1 } 2 7}$. Concentrations reported in different environments are summarized in Table 2. Different environments where antibiotics occur are depicted in Figure 1.

In summary, in a large range of environments, antibiotics occur at subMICs, including a substantial proportion of total antibiotic exposure time for the tissues of humans and animals receiving antibiotic therapy. Moreover, high concentrations are typically associated with spatial and temporal concentration gradients ranging from super-MICs to sub-MICs. It is therefore of interest to understand whether sub-MICs affect bacteria, and in what way.

1.2 ANTIBIOTIC RESISTANCE EVOLUTION

\section{Global antibiotic resistance problem}

$\mathrm{G}$ enes whose products confer bacteria resistance to antibiotics are ancient, diverse and prevalent in nature, particularly in soil, paralleling the evolution and ecology of antibiotic synthesis genes. ${ }^{1,2,28,29}$ However, in recent decades, the prevalence of antibiotic resistant (AR) bacteria and genes (ARGs) has increased in human and animal healthcare, as well as in certain human-impacted environments. Furthermore, positive correlations have been frequently found between this trend and levels of human antibiotic use..$^{30-36}$ Although bacterial strains infecting humans and animals usually differ ${ }^{37}$, as do human, animal, and environmental bacterial communities, there are also indications of AR strains and ARGs spreading at the human-animal-environment interface ${ }^{35,38,39}$. This raises concerns about the potential role of environmental antibiotic residuals in the occurrence and enrichment of AR human and animal pathogens..$^{\circ}$

The successive emergence of antibiotic resistance in clinically relevant bacteria, often within just a few years after the introduction of an antibiotic to the market, has gradually produced a global medical crisis: certain forms of resistance are prevalent, with resistance being detected against most of the antibiotics available. ${ }^{11,42}$ This includes last-resort antibiotics prescribed only after the failure of conventional therapies. ${ }^{43}$ Emerging antibiotic resistance decreases the efficacy of first-line antibiotic therapies prescribed prior to susceptibility testing, resulting in prolonged duration of disease and increased incidence of sequelae and death. Although the occurrence of clinically relevant AR strains mirrors geographic patterns in antibiotic consumption, strains and their resistance determinants spread through travelers and foodstuff across the globe. ${ }^{44}$

The antibiotic resistance crisis is exacerbated by the lack of financial incentives for pharmaceutical companies to invest in new antibiotic discovery for reasons including high competition and low expected profits compared to drugs for chronic illnesses. 45 The demand for low manufacturing costs can also feed back into the antibiotic resistance problem by driving generic antibiotic production to countries where plant emissions tend to be high, such as India. ${ }^{6}{ }^{6}$

The antibiotic resistance crisis comes at a time in human history when globally increased lifespans, the ability to treat serious medical conditions and accessibility to medical treatment have resulted in an increased number of immunocompromised people..$^{47,48}$ As their body's ability to fight infections is weak- 


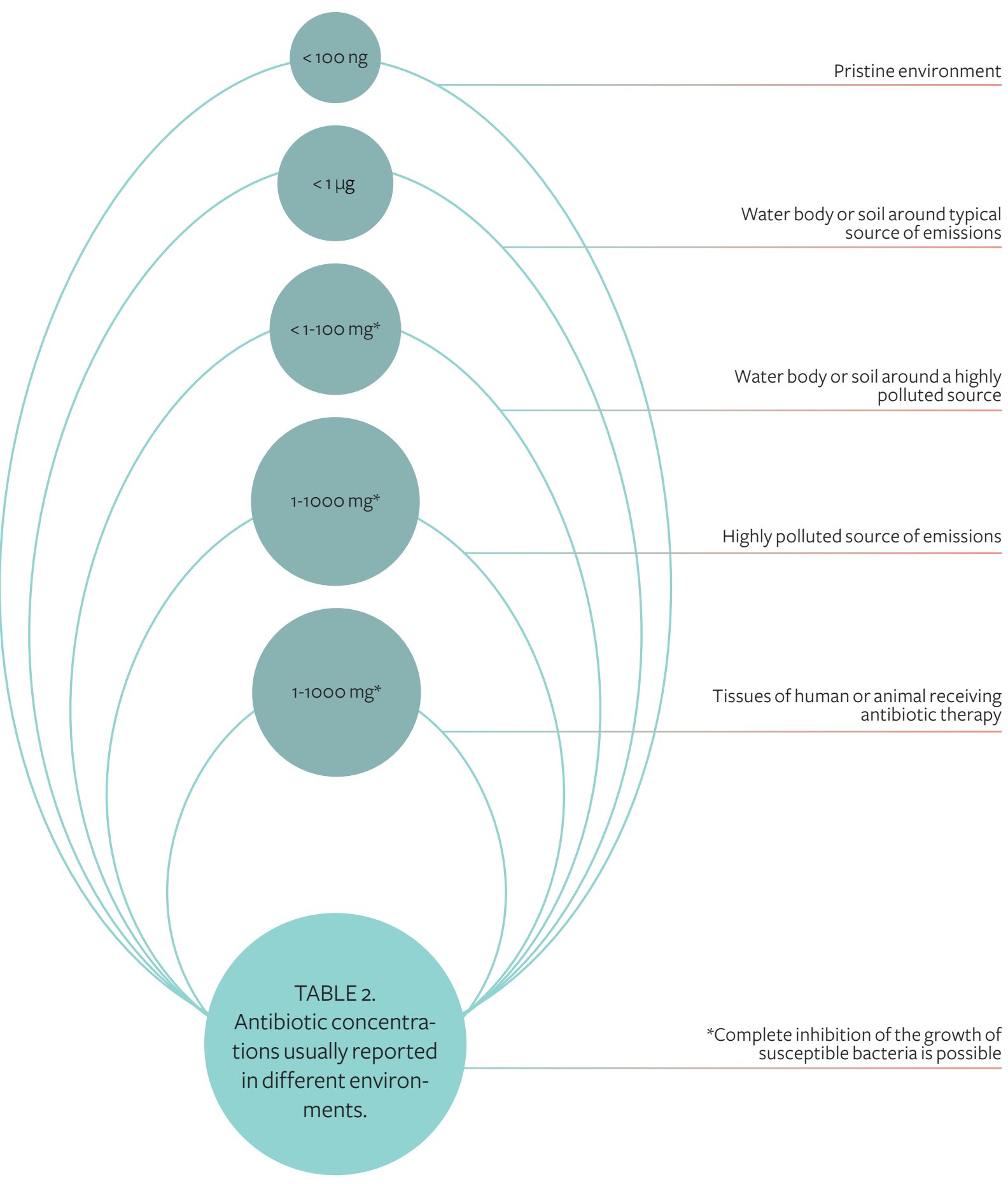


also account for the failure of first-line antibiotic therapies. ${ }^{55}$

The increase in antibiotic resistance is essentially an evolutionary phenomenon, resulting from natural selection and drift acting on genetic variability produced by mutation, recombination and gene flow (comprising the five classical evolutionary forces). In bacterial populations, gene flow and recombination especially occur through HGT. HGT is estimated to account for up to $25-33 \%$ of the genes in bacterial genomes ${ }^{56,57}$, where they belong to the variable accessory genome as opposed to the conserved core genome ${ }^{58}$. Bacterial AR phenotypes caused by both mutations and HGT are observed frequently, although the precise relative contribution of each is unclear. ${ }^{59}$ The ecology and evolution of AR mutations and HGT are discussed separately below, with special regard to the potential role of sub-MICs.

\subsubsection{ADAPTIVE RESISTANCE}

\section{Emergence and fitness effects of antibiotic resistance mutations}

Mutation supply rate, i.e. the number of mutations produced over one generation, is the product of effective population size and mutation rate. $\mathrm{Mu}-$ tation supply over a fixed time interval is therefore inversely proportional to generation time. Bacteria can have large population sizes and short generation times, and therefore high mutational potential, relative to eukaryotes. Bacterial mutation rate is primarily determined by replication error rate, defined by the fidelity of DNA polymerase, a typical mutation rate being $1 / 300$ mutations per genome per replication. ${ }^{6}{ }^{\text {Furthermore, both genetic and }}$ inducible factors can increase mutation rate by up to several orders of magnitude. For instance, mutator strains with high mutation rates can be caused by mutations in genes encoding components of the mismatch repair (MMR) system that performs post-replicative error correction. ${ }^{61}$ Moreover, the presence of single-stranded DNA in a bacterial cell due to cellular damage induces the SOS response, causing recruitment of low-fidelity DNA polymerases to continue replication, thereby increasing the mutation rate. ${ }^{62}$

Most mutations are point mutations (i.e. single nucleotide polymorphisms, SNPs), including single-base substitutions, insertions and deletions. Together the latter two are referred to as INDELs, which can also be longer. INDELs that alter the reading frame of a gene are called frameshift mutations. In addition to replication errors, var- ious mechanisms can cause structural variations in bacterial chromosomes, which also contribute to bacterial mutation supply. These include large insertions, deletions, inversions, translocations (i.e. relocation of a chromosomal segment) and duplications. Among these, duplications (often adjacent, i.e. tandem) or deletions and inversions result from homologous recombination between repeated sequence elements and inverse-order repeated sequence elements, respectively. ${ }^{63}$

Non-synonymous (amino acid altering) point mutations and frameshift mutations in the coding sequence of a gene are likely to affect the fitness of a bacterium. Recently, synonymous (amino acid preserving) mutations in coding sequences have also been shown to affect fitness due to codon usage preferences in genomes (e.g. codon composition biased to host tRNA pool) ${ }^{64,65}$ Structural variations can also affect fitness through a number of mechanisms. For instance, gene duplications increase the amount of the gene product, potentially altering the functioning of the cell. Most mutations that have a fitness effect are deleterious ${ }^{66}$, since alterations in the amino acid sequence of a protein can produce a misfolded, improperly functioning or non-functional protein. More generally, the likelihood of a random mutation to improve a cellular structure or function is lower than the likelihood of impairment. Notably, a subset of deleterious mutations is lethal, and the mutation supply rate is therefore higher than the number of surviving mutations that can be experimentally detected.

Random mutations that produce AR pheno- 
TABLE 3. Examples of point mutations causing antibiotic resistance.

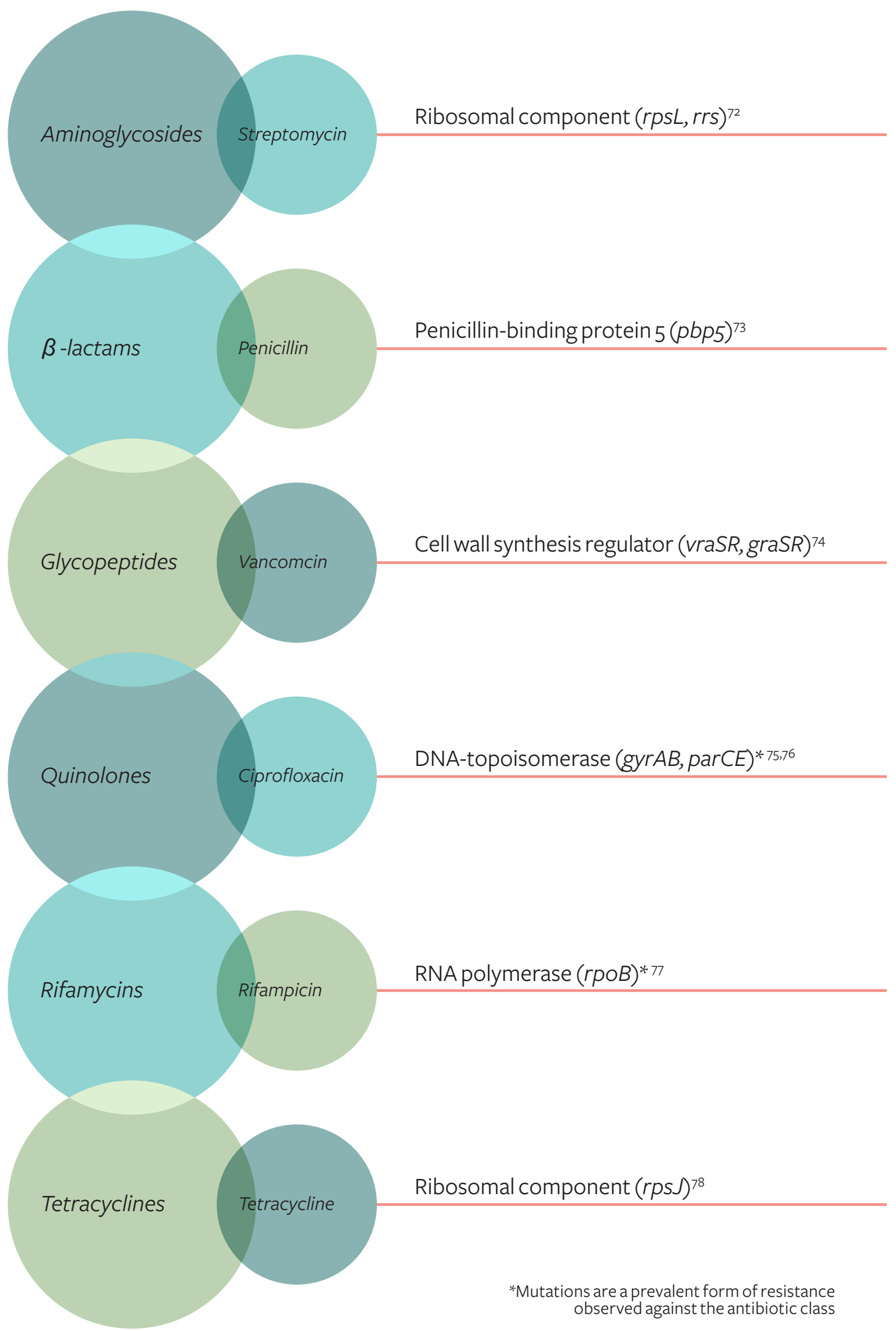


types are likely to have adverse fitness effects in the absence of antibiotics. ${ }^{67}$ One reason for this is that mutations generally have a negative effect on fitness. Furthermore, since antibiotics usually target key cellular functions, resistance mutations might have stronger negative effects than random mutations have on average. This phenomenon is referred to as the fitness cost of resistance. Fitness costs of adaptive mutations represent antagonistic pleiotropy whereby a beneficial mutation is coupled with a negative effect on another trait. Although common, not all AR mutations carry fitness costs. Empirical findings range from $>50 \%$ to little or no fitness cost. ${ }^{68}$ The variability in fitness costs can result from the different physiological effects and genetic and ecological backgrounds of resistance mutations. Although unlikely, certain AR mutations might even have synergistic pleiotropic (i.e. fitness-beneficial) effects on other traits, which can result in increased fitness in the absence of antibiotic. ${ }^{69}$

SNPs conferring resistance to different antibiotic classes readily evolve in laboratory experiments and are an important reason for AR infections in the clinical context. SNPs displaying resistance to several antibiotics (synergistic pleiotropy) of the same or even different classes can also occur due to the antibiotics affecting the same cellular function or component. ${ }^{70}$ Examples of SNPs causing antibiotic resistance are shown in Table 3. Among other frequently occurring mutation types, duplications of genes encoding antibiotic efflux pumps produce phenotypes with higher levels of antibiotic resistance..$^{11}$

\section{Antibiotic concentration required for selection of resistance}

Antibiotic concentration can affect antibiotic resistance evolution in two ways. It can affect the fate of the same mutation occurring in the same genetic background, and it can affect the type of mutation selected. The fate of the same mutation is affected by its associated fitness cost and interference interactions within the genome, population and community. For selection to occur, the antibiotic concentration must first exceed the minimum selective concentration (MSC), denoting fitness neutrality compared to susceptible cells (Figure 2A). ${ }^{79}$ At the MSC, drift and selection act equally on the mutation, and a rare AR mutation is likely to be lost through drift. One study reports MSCs to different antibiotics ranging between $1 / 4$ and $1 / 230 \times$ MIC..$^{79}$ In another study examining 111 antibiotics and 11 antibiotic combinations, upper boundaries for MSCs were estimated to range between $69 \mu \mathrm{g}$ and $32 \mathrm{mg} \mathrm{l}^{-1}$ and concentrations below $8 \mathrm{ng}$ to $64 \mu \mathrm{g} \mathrm{l}^{-1}$ to cause no selection for resistance (see Table 2 for concentrations occurring in different environments). ${ }^{80}$ Therefore, both the MSC and its relation to MIC vary by several orders of magnitude among different antibiotics.

In asexually reproducing organisms like bacteria, adaptive mutations cannot be purged from background mutations, including deleterious mutations, through recombination. ${ }^{81}$ For an adaptive mutation to be selected in a linked genome, its selection coefficient (fitness benefit) must exceed a characteristic threshold representing the typical level of interference (Figure 2B). ${ }^{82}$ The antibiotic concentration where selection for resistance is likely to occur therefore exceeds the MSC by a certain threshold. Starting from this concentration, the strength of selection increases with increasing concentrations. In the extreme case, only one clonal lineage can survive in the concentration. In this scenario, the mutation and all the background mutations (hitchhikers) become fixed in the population even 
when the genetic background includes deleterious mutations. This is called a selective sweep (Figure 2C).

Moreover, in asexually reproducing organisms, adaptive mutations frequently occur in different lineages in the population. Again, because of linked genomes, adaptive mutations in separate lineages cannot recombine to the same genome, causing competition between lineages (Figures $2 B$ and $2 D$ )..$^{81,83,84}$ Such clonal interference decreases the strength and directionality of selection. Therefore, even with a positive combined fitness effect of the mutations in a genome including an AR mutation, at the lower selective concentration range, other equally adaptive genotypes are likely to emerge in other lineages, causing interference on AR selection. For a selective sweep of an AR mutation to occur in a bacterial population, the antibiotic concentration, and thereby, the fitness benefit of the resistance mutation must surpass this interference effect.

In addition to clonal interference, ecological mechanisms maintaining species coexistence can also interfere with directional selection at the community-level (Figures $2 E$ and $2 F$ ). These include niche partitioning through spatial or resource use separation, and balancing selection mechanisms. For instance, cross-feeding interactions are common between bacteria. Here, one bacterium is a superior competitor for an exogenous resource and another bacterium uses a byproduct of this member. This creates negative frequency dependent selection where bacterial fitness increases with decreasing frequency, allowing stable coexistence of the bacteria. ${ }^{85}$ For competitive dominance of an AR genotype, the fitness benefit of the AR mutation might need to surpass also the forces maintaining stable coexistence of species in a community.

Instead of only one particular mutation conferring antibiotic resistance to a particular antibiotic, there is usually a whole range of AR mutations that have different fitness costs in the absence of antibiotic and that confer different levels of resistance. These range from high-level resistance mutations specifically targeting the antibiotic to low-level resistance mutations affecting aspects such as stress tolerance, and from common point mutations to rare mutational combinations and structural variations. Intermittent antibiotic exposure can also select for tolerance mutations, such as mutations increasing the lag phase of cells, allowing short-term survival under antibiotic exposure. ${ }^{87}$

Antibiotic concentration can affect both the size of the mutational space and which mutations in the space are selected. The lower the concentration is in the selective range, the more genetic variability can be maintained, increasing the supply of adaptive mutations both in space and over time. A higher supply of mutations increases the chance of the occurrence of rare AR mutations or mutational combinations that are either fitness-neutral or even -beneficial in the absence of antibiotics. ${ }^{88}$ Since the fitness effect of an AR mutation is determined by the benefit provided minus the cost in the absence of antibiotic, the lower the concentration, the lower the cost and the more fitness-beneficial the genetic background must be for a mutation to be selected. ${ }^{8}$ Furthermore, since by definition the MIC completely inhibits the growth of susceptible cells, only rare high-level resistance mutations will be selected at super-MICs. High-level resistance mutations are more likely to be physiologically coupled with higher fitness costs due to having a stronger effect on the cellular function targeted by the antibiotic. ${ }^{69}$ Together these factors result in enhanced selection for low-cost AR mutations at sub-MICs compared to super-MICs. Such low-cost resistance might or might not be associated with high-level antibiotic resistance, which, 


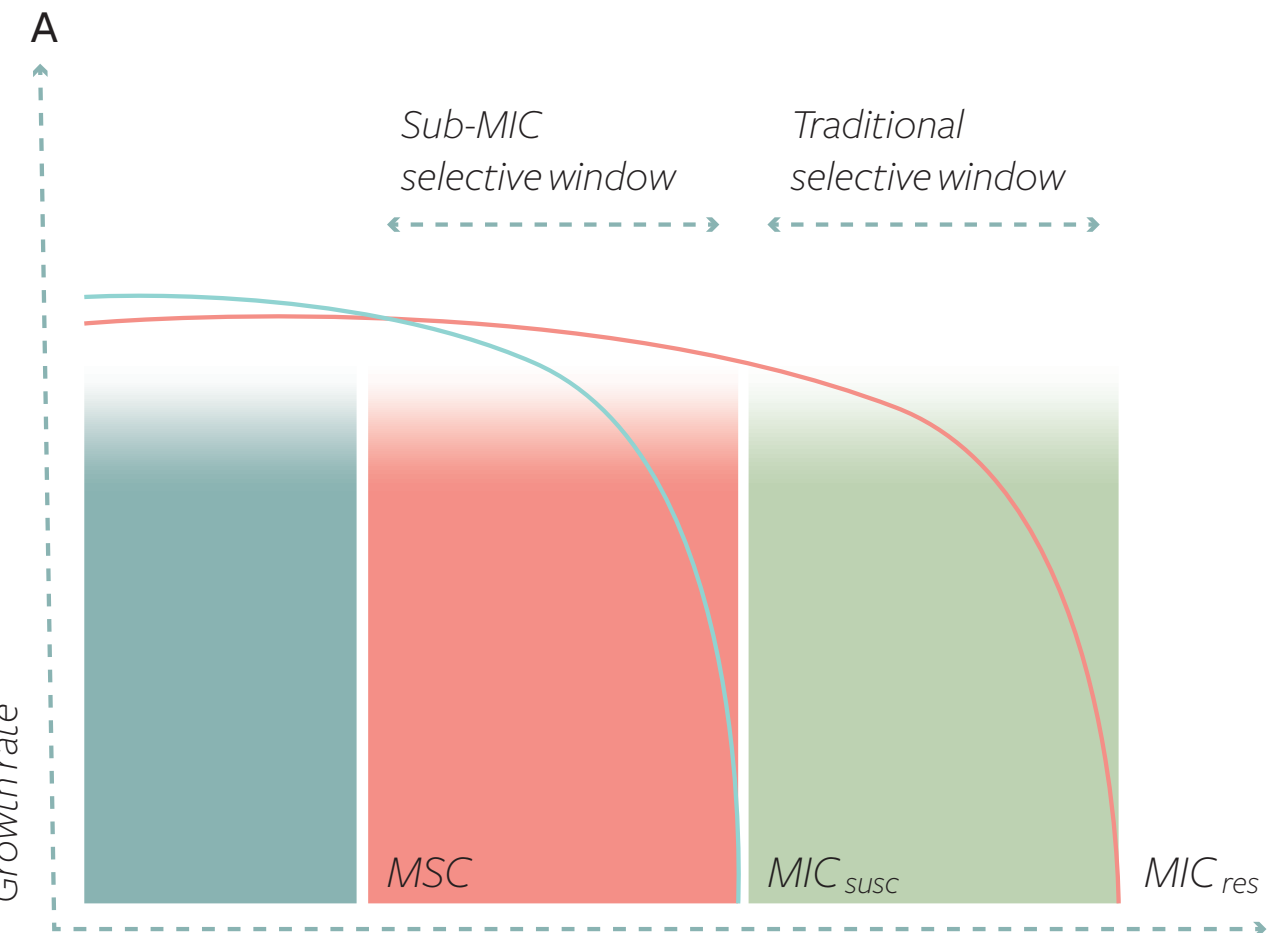

Antibiotic concentration

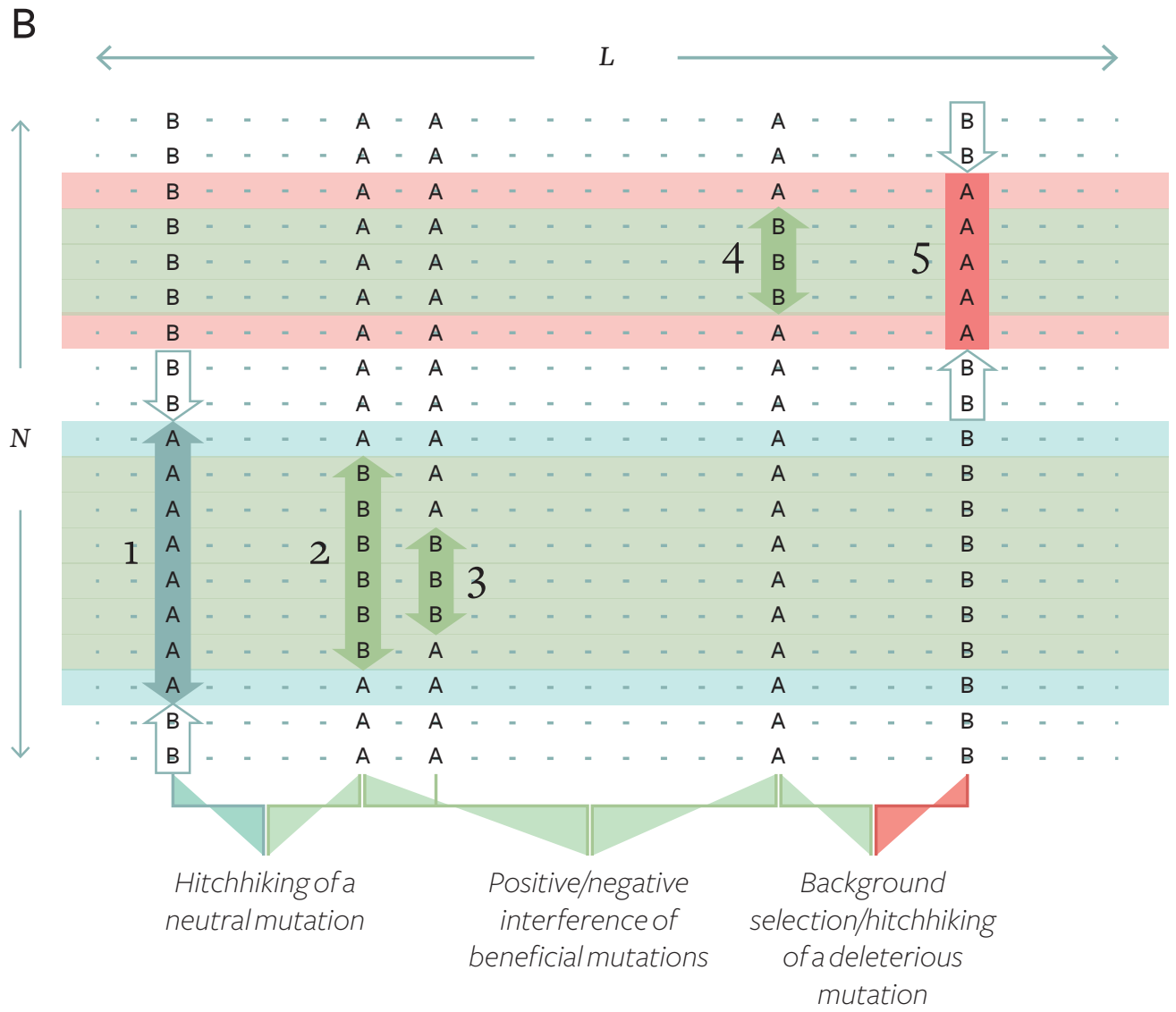


C

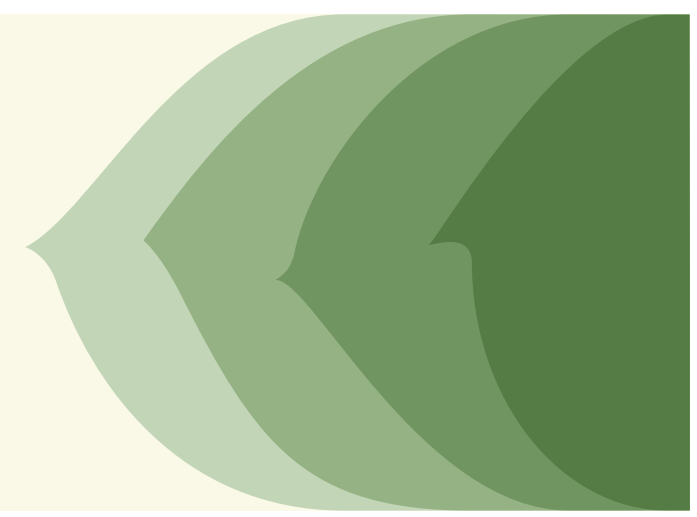

$\mathrm{E}$

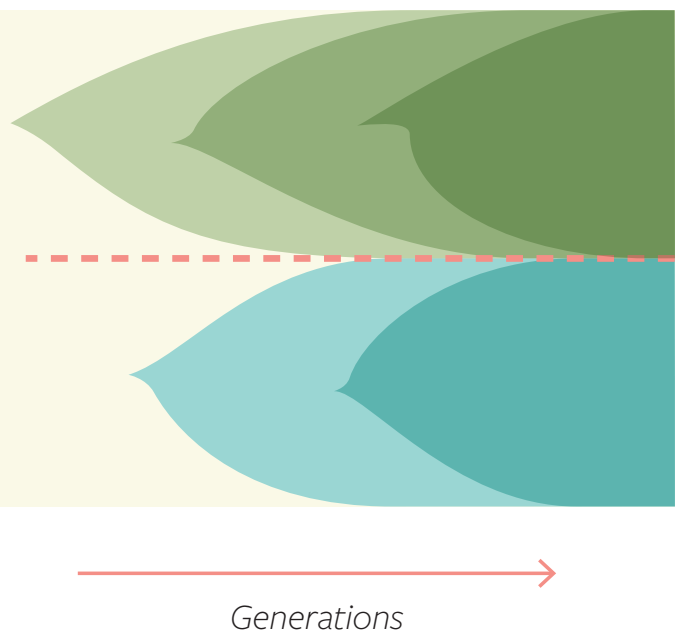

D

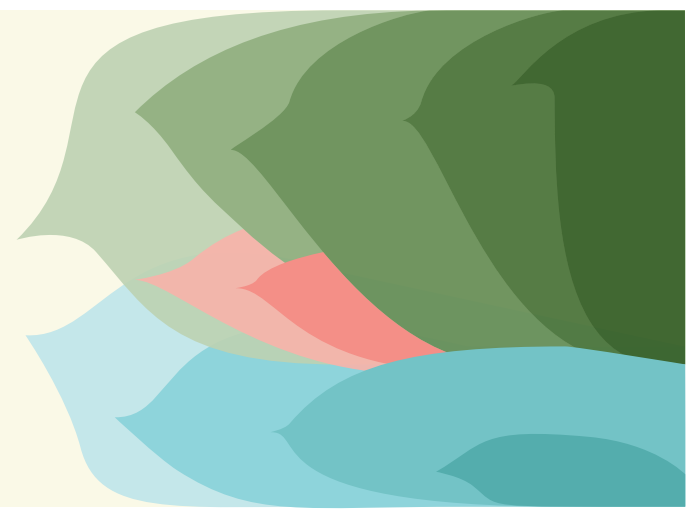

$\mathrm{F}$

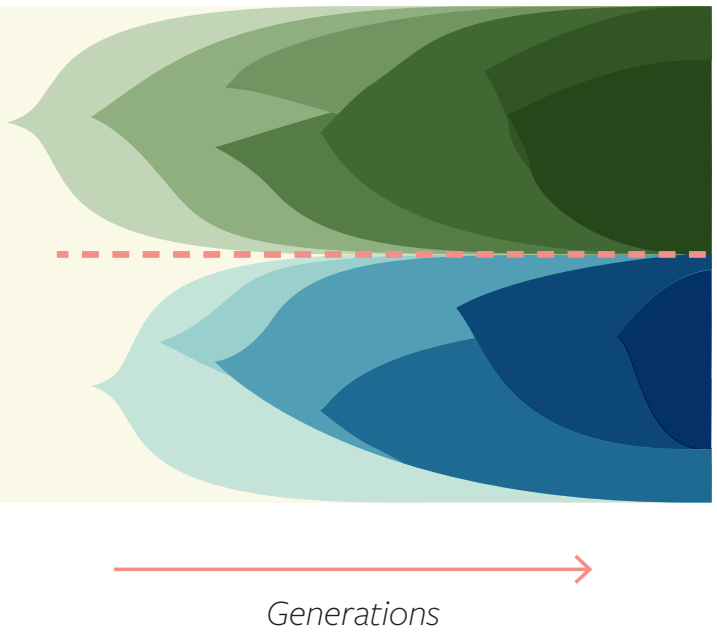

FIGURE 2 | Population genetic and ecological mechanisms affecting antibiotic resistance mutational trajectories. (A, on previous page) Any concentration above the minimum selective concentration (MSC) where the growth rate of a resistance mutant (red line; "res") exceeds the growth rate of a susceptible cell (blue line; "susc") can select for antibiotic resistance. This includes concentrations both above and below the minimum inhibitory concentration (MIC) that completely inhibits the growth of a susceptible cell. Modified from Gullberg et al. $2011 .{ }^{79}$ (B, on previous page) In a non-recombining population of $N$ individuals with two-nucleotide genomes of length $L$, evolution is affected by positive and negative interference interactions between beneficial (green), neutral (blue) and deleterious mutations (red). Here, alleles 2 and 3 may drive hitchhiking allele 1 to fixation, and compete with allele 4, which may either drive allele 5 to fixation or be driven to loss by it. Modified from Schiffels et al. 2011. ${ }^{82}$ (C-F) Periodic selective sweeps (C, E) and clonal interference (D, F) at the population (upper panels) and community level (lower panels; two species/genotypes are separated by a dashed line). Modified from Marx $2013 .{ }^{86}$ The color codes in A, B and C-F are unrelated.

Original illustration courtesy of Matti Ruuskanen, re-rendered by No Jam Studio. 
owing to these same factors, is specifically enhanced by exposure to a gradient of increasing antibiotic concentrations.

Adaptation frequently involves more than one mutation, and mutations often interact, a phenomenon known as epistasis. ${ }^{89}$ Positive and negative epistasis denote a situation where two mutations in combination produce higher or lower fitness, respectively, than the sum of the counterparts. Sign epistasis denotes a situation where the sign of a mutation (fitness-beneficial or -negative) changes depending on the presence of another mutation. Epistatic interactions have been shown to be altered by antibiotic concentration, such that the mutational combinations producing optimal fitness differ. ${ }^{90}$ Thus, different mutational combinations are selected at different antibiotic concentrations. Furthermore, the largest amount of antibiotic resistance evolutionary potential (mutational combinations) is produced by exposure of a bacterial population to a range of concentrations rather than a single antibiotic concentration.

Concerns have been raised about the potential threat imposed by sub-MICs that can select for low-cost, and occasionally high-level, AR mutations. ${ }^{79,88}$ However, compared to super-MICs, these concentrations also produce weaker selection because of smaller selection coefficients and increased interference interactions. Furthermore, AR mutants selected at super-MICs also frequently evolve to grow similar to susceptible cells in the absence of antibiotics through accruing secondary-site beneficial mutations that compensate for the fitness cost of resistance. ${ }^{91}$ Overall, the amount of quantitative data on key parameters is currently insufficient for accurate predictions concerning AR mutational trajectories at different concentrations. ${ }^{92}$ The modes in which decreasing antibiotic concentrations are likely to alter the evolution of antibiotic resistance are summarized in Table 4.
1.2.1 ACQUIRED RESISTANCE

Horizontal gene transfer and mobile genetic elements

Genes conferring AR phenotypes can be acquired without host mutations horizontally from other bacterial cells representing the same or a closely related species, or even disparate bacterial taxa. HGT occurs through four mechanisms: transformation, membrane vesicles, transduction and conjugation. Natural transformation is the direct uptake of environmental DNA by bacteria. The DNA is typically bound to a type IV pilus, transported to the cytoplasm and integrated into the host chromosome via homologous recombination or reassembled as an independently replicating molecule. Functional ARGs can be transferred through transformation. ${ }^{93,94}$ Antibiotics that disturb cell wall synthesis might also improve the transformation competency of cells, increasing HGT via transformation. ${ }^{94}$ However, functional gene transfer via transformation might be uncommon, in part, because of the requirement for sequence homology with host for recombination to occur. Transfer of DNA, including ARGs, can also occur between two cells via membrane vesicles ${ }^{95,96}$, although the prevalence of this HGT mechanism is unclear.

Transduction refers to HGT mediated by viruses that infect bacteria (bacteriophages, or simply, phages). In transduction, packaging of specific or nonspecific parts of the host chromosomal DNA into phage particles, defined as specialized or generalized transduction, respectively, is followed by integration of the DNA into the genome of an infected host through homologous recombination. Transduction has been shown to transfer ARGs, and the abundance of ARGs in environmental viromes suggests that the role of transduction in ARG transfer might be unappreciated..$^{97,98}$ In addition to HGT through transduction, phages that integrate as prophages to the host genome (i.e. temperate phages) can also alter host phenotype as well as encode superinfection immunity against co-infection of the cell by another phage. In superinfection immunity, the resident prophage expresses repressor proteins that block the genome functioning of 
TABLE 4. Effect of decreasing antibiotic concentration on resistance evolution.

\section{Feature}

Fate or nature of resistance mutation

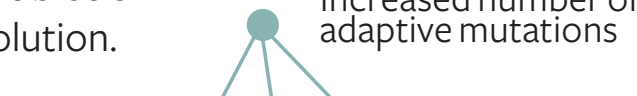

Decreased selection for high-level resistance mutations

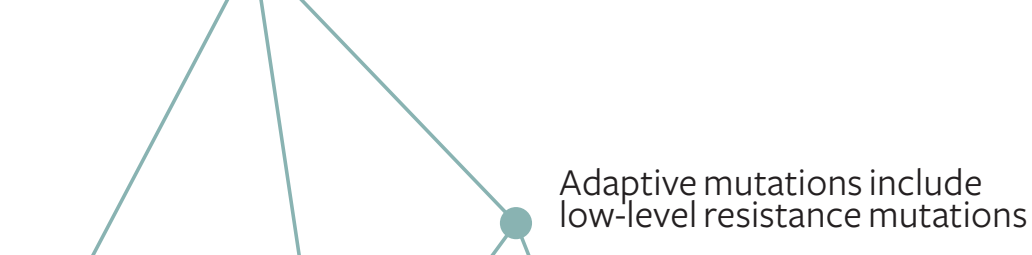

Altered targets of compensatory mutations

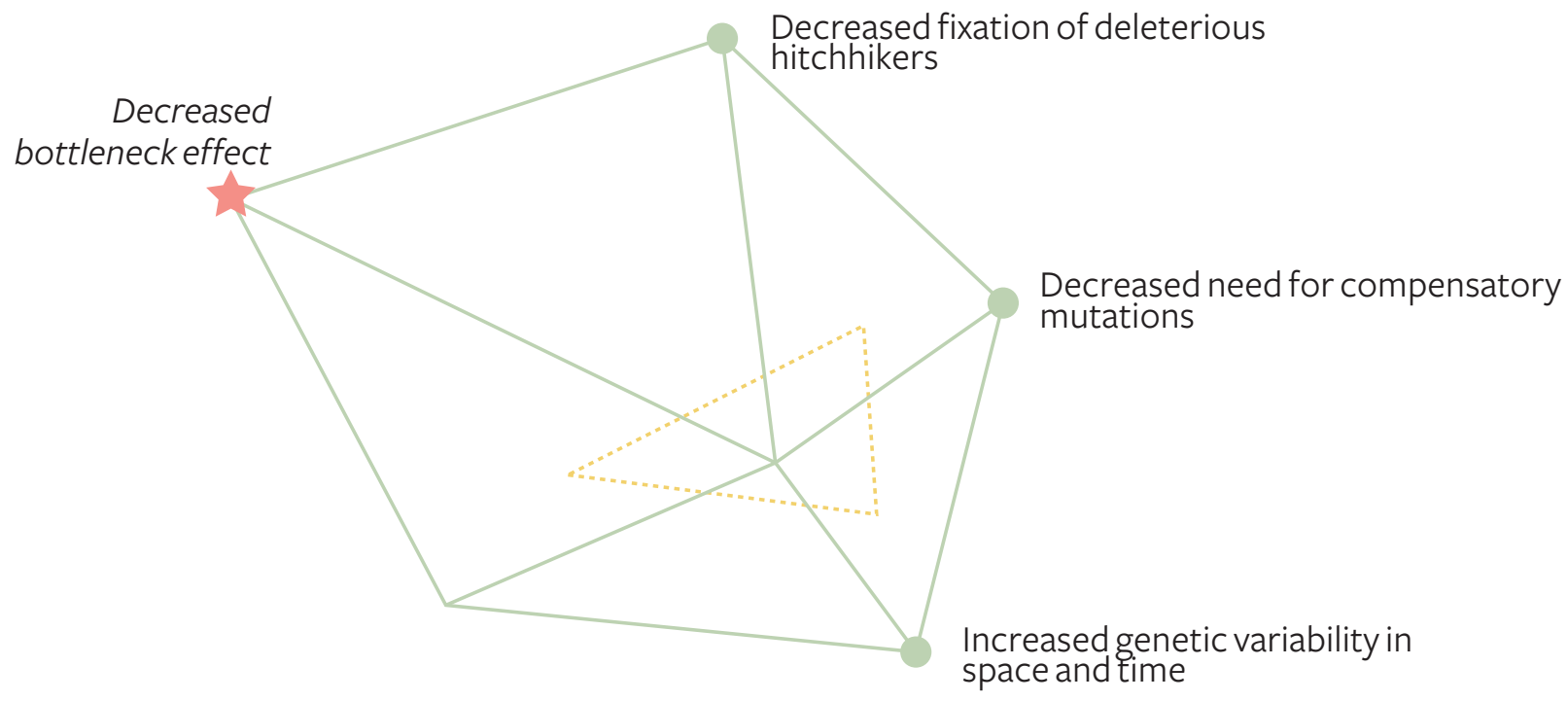

Different mutational combinations produce optimal fitness 

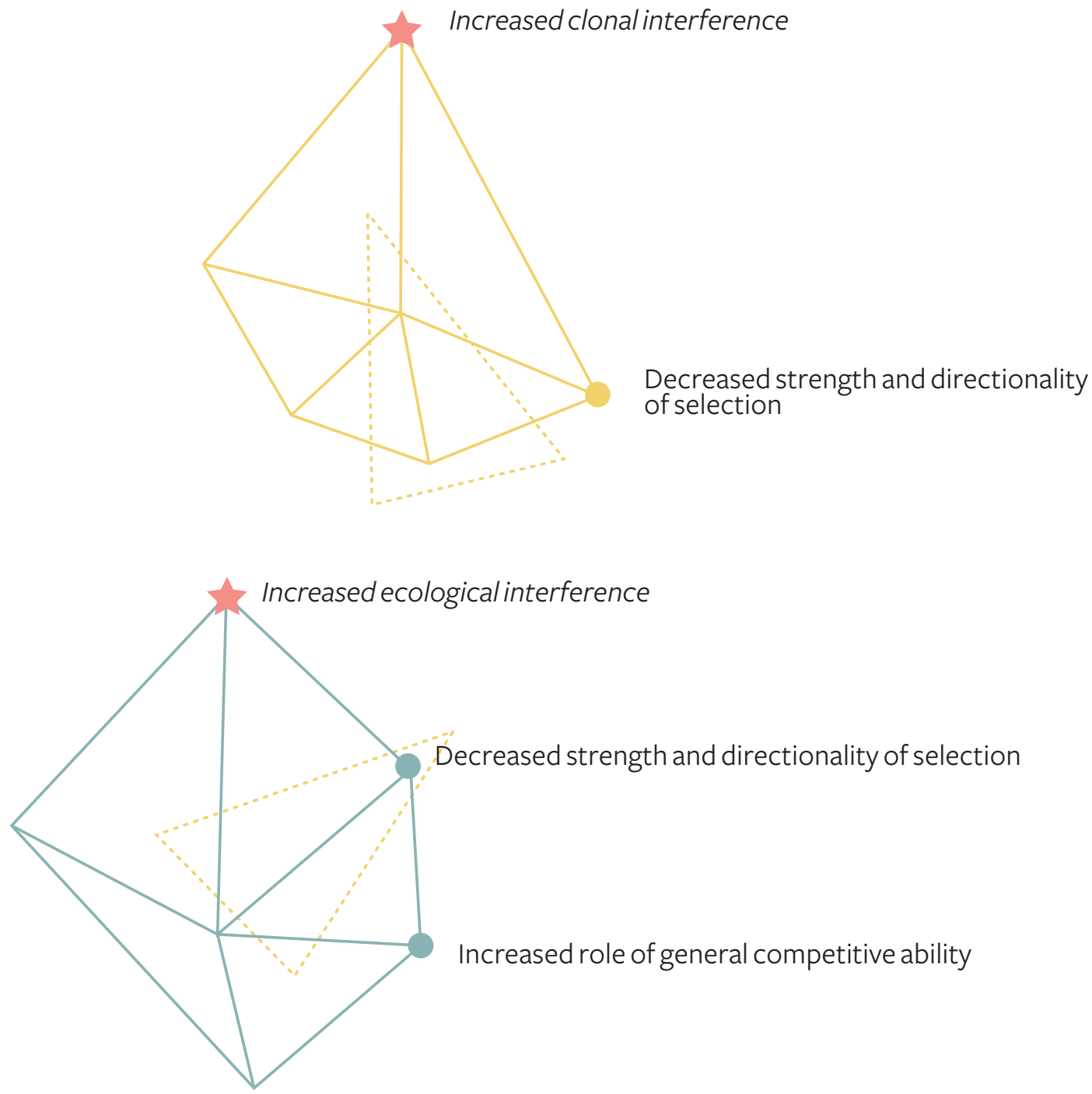

Decreased strength

of selection
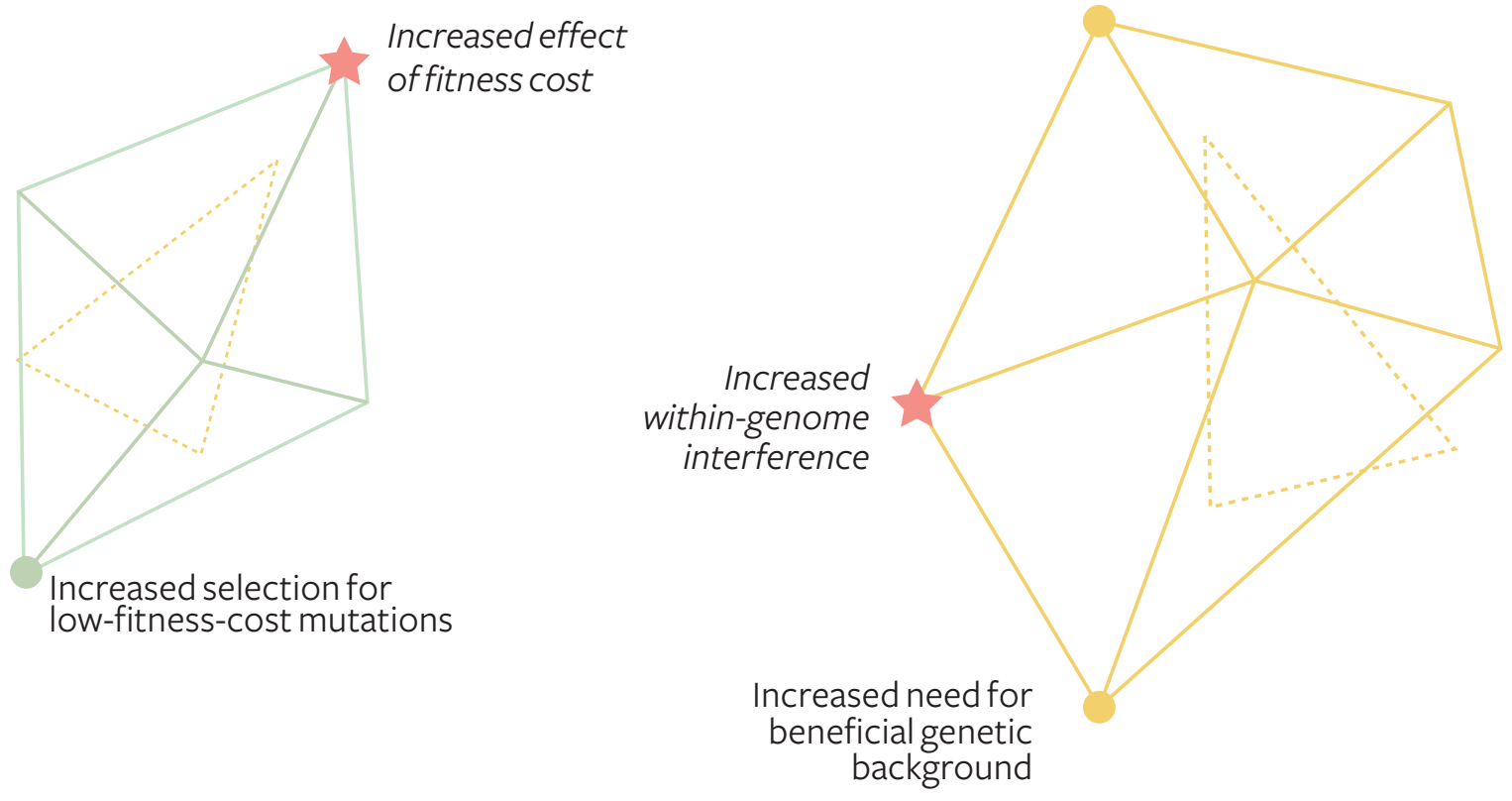
a secondary (superinfecting) phage whose genome has successfully entered the cell. This might inhibit HGT through transduction, although mobilization of functional ARGs to the host cell from a transducing phage despite inability of the phage to replicate due to superinfection immunity has been shown. ${ }^{99}$ Antibiotics might also increase transduction by inducing prophages (excision from chromosome and initiation of lytic cycle), allowing the phages and the ARGs they carry to infect and integrate to the genomes of other bacterial lineages. ${ }^{100}$

Conjugation is the transfer of DNA from donor to recipient cell (both inter- and intra-specifically) via cell-to-cell contact established by a type IV pilus. The DNA transferred is usually an independently replicating extrachromosomal molecule, a plasmid, which frequently encodes beneficial accessory traits. Acquisition of plasmid-located ARGs, which can confer resistance to all major antibiotic classes, represents a highly prevalent mechanism causing antibiotic resistance in bacterial pathogens in the clinical context (Table 5).${ }^{101}$ These include genes encoding extended-spectrum-lactamases ${ }^{102}$ and vancomycin resistance ${ }^{103}$ in the critical and high priority pathogens in the World Health Organization priority pathogens list. ${ }^{104}$ Plasmids are also the most important source of multidrug resistance due to either co-occurring ARGs or point mutations increasing ARG activity range. ${ }^{105,106}$ There is high variation in plasmid copy number, stability, and gene content, with sizes ranging from less than $1 \mathrm{~kb}$ to more than $1 \mathrm{Mb}$. Moreover, plasmids can also be non-conjugative, although some among them (small multicopy plasmids) are horizontally mobilizable by the presence of a conjugative plasmid in the same host bacterium. ${ }^{107}$ In addition to conjugative plasmids, integrative and conjugative elements (ICEs) are mobile genetic elements (MGEs) integrated to the host genome which encode a functional conjugation system and can transfer between cells. ${ }^{108,109}$

Integrons and transposable elements, which include transposons and insertion sequences, are also important MGEs. However, with the exception of conjugative transposons, which belong to ICEs, they lack HGT mechanisms of their own. DNA transposons are sequences that can change their location within or between DNA molecules through a cut-and-paste mechanism catalyzed by transposase enzymes, and they generally carry accessory genes. Insertion sequences are small transposable elements that only encode proteins required for transposition. A composite transposon is a transposon flanked by insertion sequences that is mobilized as a complete unit. Integrons are promoter-containing assembly platforms that collect genes into a series of gene cassettes, by site-specific recombination mediated by an integrase enzyme, and ensure their expression. ${ }^{118}$ These gene cassettes frequently contain ARGs. ${ }^{119}$ The MGEs participate in HGT interactively: gene cassettes collected by integrons can be incorporated into transposons. ${ }^{118}$ The transposons can subsequently be mobilized between host chromosomes by plasmid intermediates. ${ }^{120,121}$ The process has resulted in highly mosaic MGE structures. Clusters of genes in bacterial genomes acquired by HGT are called genomic islands, which in the clinical context frequently encode virulence and AR traits. ${ }^{122}$

\section{Conjugative plasmid dynamics}

Among the MGEs, conjugative plasmids play a disproportionately important role in HGT due to their ability to mobilize not only themselves and the genes 


\section{TABLE 5.}

Examples of antibiotic resistance gene groups located on plasmids.

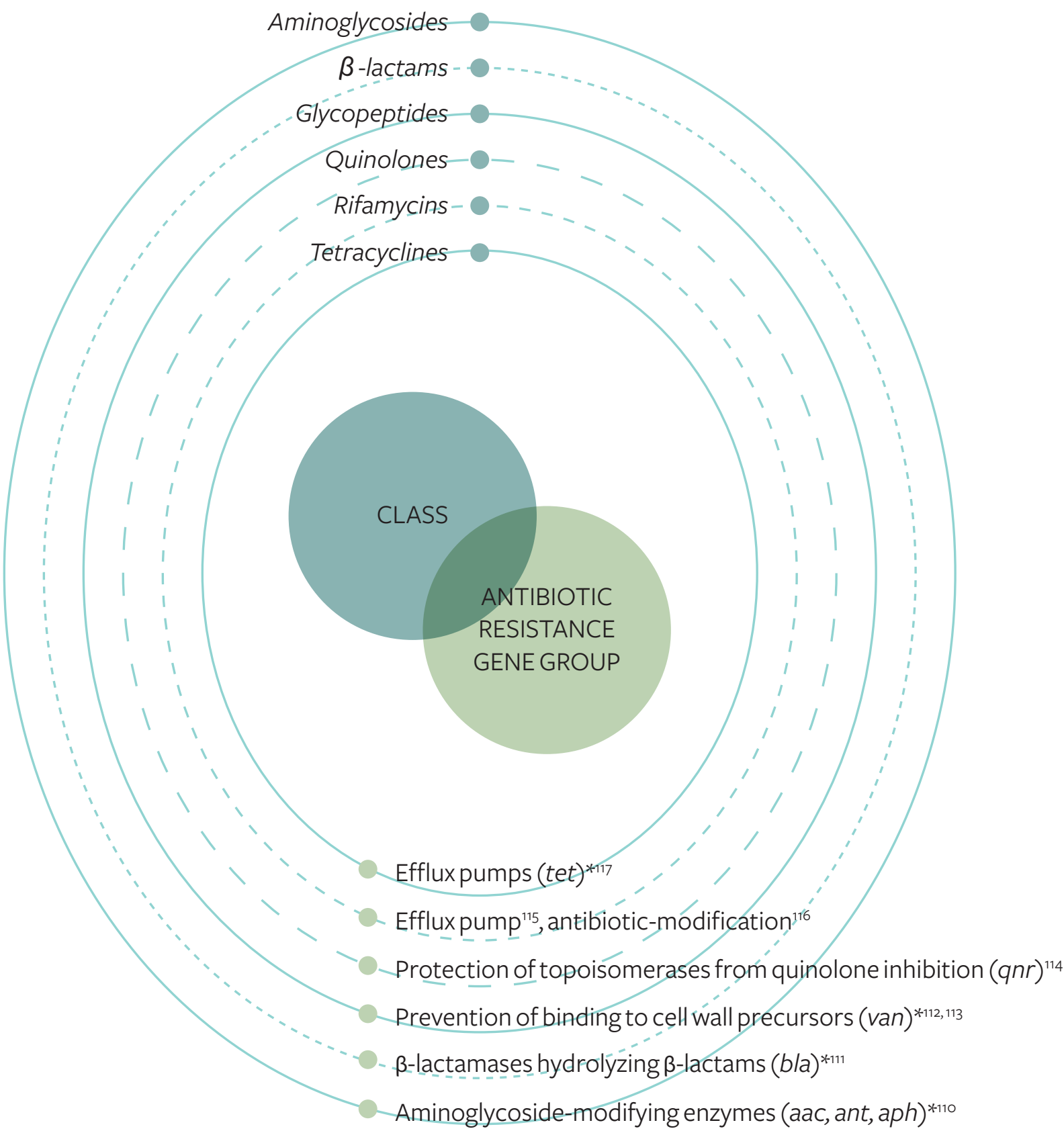

* Plasmids are a prevalent source of resistance observed against the antibiotic class 
they carry but also non-conjugative plasmids ${ }^{123}$, transposable elements ${ }^{120}$, integrons ${ }^{118}$ and nonspecific host DNA elements ${ }^{124}$. Factors governing the transfer and selection of conjugative plasmids are therefore important determinants of antibiotic resistance.

Plasmid conjugation is a biomolecular reaction in which a donor cell transfers a plasmid to a recipient cell (transconjugant). The potential for and likelihood of plasmid transfer is affected by a variety of factors. First, to maintain the plasmid, the recipient cell must be within the host range of the plasmid, and must not contain another, incompatible plasmid. The host range of a plasmid can be narrow or broad. Narrow host range plasmids can transfer only among closely related species. Broadest host range plasmids exhibit transfer across diverse gram-negative bacteria. ${ }^{125}$ Inter-gram plasmid transfer has also been documented, especially from gram-positive to gram-negative bacteria ${ }^{126-128}$, as well as conjugative plasmid transfer from bacteria to microbial eukaryotes ${ }^{129}$.

The host range of a plasmid is determined by its physical ability to transfer to another cell and, more importantly, by its replication system and interaction with host factors. ${ }^{130}$ The type IV secretion system involved in the physical transfer of a plasmid comprises a mating pair formation (Mpf) complex and the coupling protein (CP). Plasmid-encoded Mpf components (protein complex and pilus) establish physical contact between the donor and recipient cell and create a secretion pore, and the CP delivers the DNA to the entry of the secretion pore, potentially also participating in active secretion of DNA. ${ }^{131}$ The replication of a successfully transferred plasmid requires the establishment of the replisome through DNA-protein and protein-protein interactions. A failure to replicate can be caused, for example, by deficient interaction between the plasmid origin of replication (ori) or replication initiation protein (Rep) with host proteins, deficient regulation of expression of essential plasmid genes, or instability or mislocalization of plasmid encoded proteins in the bacterial cell.

Alongside transfer to an out-of-host-range bacterium, stable maintenance of a plasmid is also prevented if the cell contains a plasmid with the same origin of replication. When the origin of replication is the same, competition for replication factors leads to rapid loss of one of the plasmids. ${ }^{132}$ Based on sharing the same replication strategy, plasmids are categorized into incompatibility groups whose members are unable to coexist in the same cell. Moreover, plasmid stability is influenced by the presence and type of mechanism for segregating plasmid copies from parent to progeny cells encoded in partitioning (par) loci. ${ }^{133}$ Plasmid incompatibility can also arise when two plasmids share the same partition mechanism. Here, incompatibility is usually thought to result from random plasmid type allocation to progeny cells, leading to gradual loss of one of the plasmids. ${ }^{133,134}$ Plasmid-host compatibility might also be affected, although not completely prevented, by other factors such as differences between codon usage preferences. ${ }^{135}$

The likelihood of plasmid transfer to a suitable recipient is defined by several factors, including donor-recipient encounter rate and conjugation efficiency. Donor-recipient encounter rate is determined both by population sizes and the physical layout of the habitat. For instance, on the one hand, structured environments (e.g. biofilms) provide increased cell-to-cell contact and stability of Mpf compared to well-mixed aqueous environments. ${ }^{136}$ On the other hand, spatial structuring can cause physical isolation of subpopulations, which might prevent plasmid spread between subpopulations.

Conjugation efficiency is affected by both donor and recipient cell physiology. Conjugation requires the expression of the conjugation machinery by the donor. This depends on the growth phase: 300-fold higher conjugation efficiencies have been observed for donor cells in the exponential growth phase compared to the stationary growth phase. ${ }^{137}$ A smaller effect is also caused by the growth phase of the recipient, such that (approx. eightfold) decreased conjugation efficiencies are observed with recipients in the exponential compared to the stationary growth phase. This could be caused by improved donor recognition of the recipient due to decreased motility or altered cell wall composition. ${ }^{137}$ 
A

No antibiotic
Conjugation

Growth

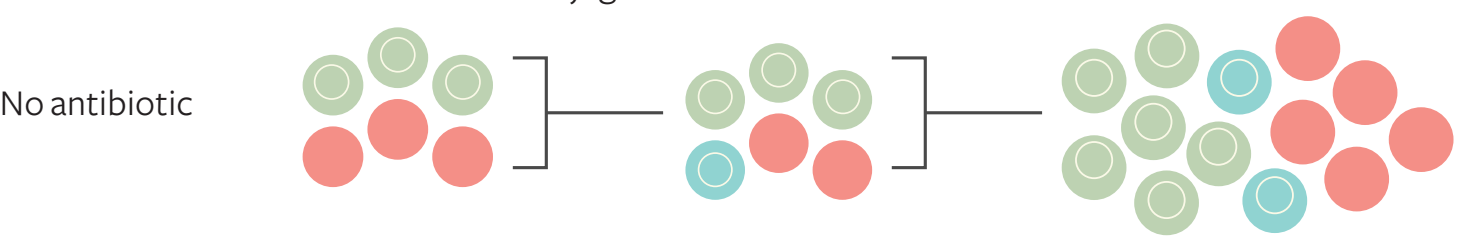

B

Antibiotic promotes conjugation
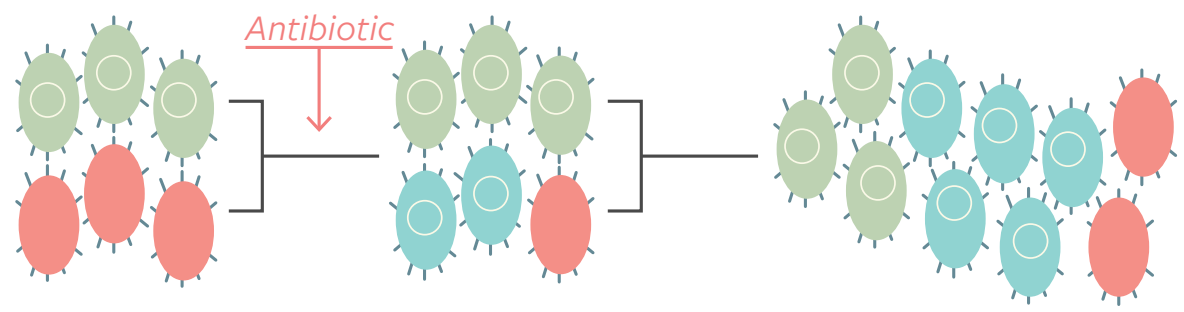

C

Antibiotic inhibits conjugation
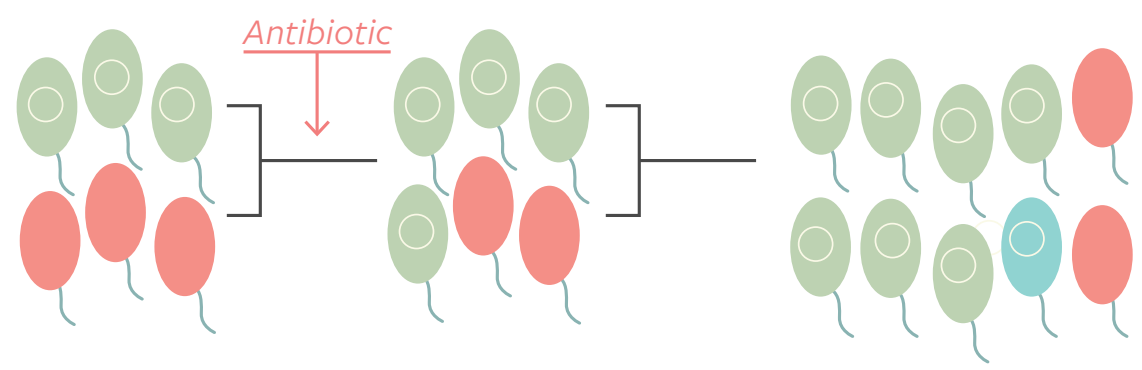

D

Antibiotic selects for transconjugants

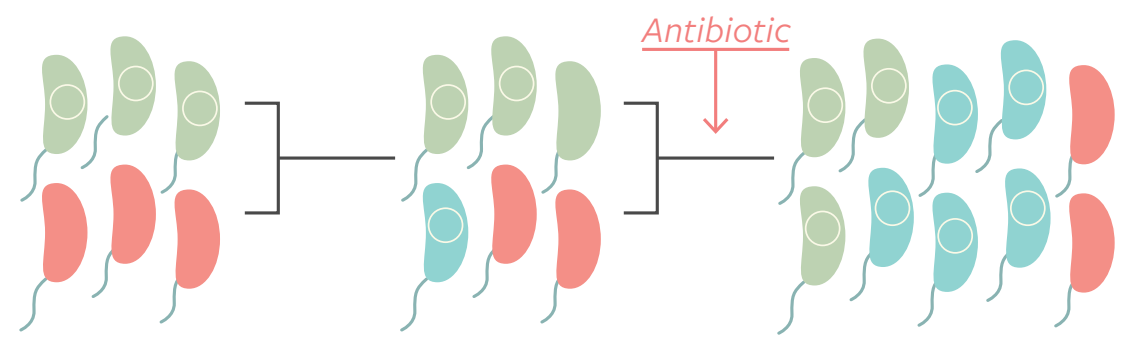

FIGURE 3 | Conjugative plasmid dynamics under antibiotic selection. Mobilization of an antibiotic resistance plasmid through conjugation from donor (green) to suitable recipient cell (red), resulting in transconjugants (blue), and increase in transconjugant prevalence are separate processes that can be differentially affected by antibiotic selection. (A) The emergence and prevalence of transconjugants in the absence of positive selection is determined by donor and recipient encounter rate, conjugation efficiency, segregation error rate and transconjugant fitness. (B) If an antibiotic causes expression of the conjugative machinery, this may increase conjugation efficiency and transconjugant prevalence. (C) Abundance changes caused by increased donor or reduced recipient fitness under antibiotic selection can, however, promote clonal expansion of the donor at the expense of conjugative transfer. (D) Antibiotics can select for transconjugants if their fitness surpasses parental strain fitness. Notably, the outcome is similar to B but the mechanism is different. Adapted from Lopatkin et al. 2016. ${ }^{137}$

Original illustration courtesy of Matti Ruuskanen, re-rendered by No Jam Studio. 
Current evidence on the effect of sub-MICs of antibiotics on plasmid conjugation efficiency is unclear (Figure 3). While sub-MICs have been shown to increase ICE conjugation efficiency by either activating the excision of genes from the chromosome or by inducing the conjugation machinery ${ }^{138,139}$, evidence for plasmids is lacking and potential enhancement is limited to cases where the conjugation machinery is not constitutively expressed (Figure 3B). ${ }^{137}$ More speculatively, sub-MICs might indirectly increase conjugation efficiency through causing global cellular responses. However, sub-MICs can also decrease plasmid conjugation frequency by reducing donor or recipient population size and thereby the encounter rate, or by causing clonal expansion of the donor (Figure $3 \mathrm{C}$ ).

Once a transconjugant emerges in a population, its selection by an antibiotic requires that it possesses higher fitness than the donor strain harboring the same plasmid and its parental strain lacking the fitness cost caused by plasmid carriage (Figure $3 D$ ). Positive selection for the plasmid causes an increase in transconjugant frequency when these conditions are met, but otherwise promotes clonal expansion of the donor at the expense of transconjugants (Figure 3C). ${ }^{121,137}$ Interestingly, sub-MICs granting the transconjugant higher fitness than either parental strain are likely to decrease conjugation frequency by reducing parent encounter rate. Therefore, the conditions under which sub-MICs promote ARG mobility might be narrow.

Compared to transconjugant selection, positive selection has a clearer role in the selection for lineages already containing plasmids. Similar to AR mutations, plasmid transfer and carriage are typically associated with fitness costs in the host cell in the absence of positive selection. ${ }^{140}$ Fitness costs of plasmids can be caused by a multitude of factors, the most important likely being the biosynthetic burden from expressing plasmid-encoded genes. ${ }^{140}$ With a sufficient fitness cost of plasmid carriage or segregation error rate resulting in plasmid-free progeny cells, the plasmid is likely to be lost from the population in the absence of sufficient positive selection or conjugation efficiency. Notably, conjugation efficiency alone can be sufficient to maintain a plasmid in a population. ${ }^{141}$ Plasmid selection and plasmid transfer are not necessarily mutually exclusive processes, since plasmid selection increases donor prevalence, and thereby, encounters between the donor and potential recipients.

\section{Differences between conjugative plasmids and adaptive mutations}

Similar to adaptive mutations, the strength of AR plasmid selection is expected to increase with increasing super-MSCs of antibiotics. However, the segregation error rate and conjugation efficiency of a conjugative plasmid can have a considerable impact on plasmid dynamics. In the extreme case, as mentioned above, positive selection is not required at all but plasmid conjugation efficiency alone is sufficient to maintain a plasmid in a population. In contrast, for adaptive mutations to increase to a high frequency, a certain duration of positive selection is required unless selection strength is sufficient to completely prevent the reproduction of individuals lacking the mutation. If an AR plasmid cannot be stably maintained in the absence of positive se- 
lection due to fitness costs or segregation error, it will be lost from the population through negative (i.e. purifying) selection or by chance, respectively, despite having swept through the population. However, for adaptive mutations that have fixed in the population, reversal to the ancestral state and, thereafter, loss from the population requires highly unlikely reverse mutations that restore the ancestral genotype. Furthermore, due to frequently encoding multiple accessory traits, a wider spectrum of conditions might create positive selection for $\mathrm{AR}$ plasmids compared to AR mutations. For instance, in addition to other antibiotics, environmental concentrations of heavy metals or detergents resulting from human activity can co-select for ARGs due to co-localization on the same plasmid as heavy metal or detergence resistance genes ${ }^{142,143}$.

Similar to adaptive AR mutations, compensatory mutations can remove the fitness effect of plasmid carriage on the host cell in the absence of positive selection. ${ }^{144-147}$ However, unlike AR mutations, in addition to the host chromosome, compensatory mutations to plasmid carriage can also occur in the plasmid with a higher gene copy number and, therefore, mutation rate compared to the host. Also, with plasmids, compensatory mutations can target aspects related to host compatibility, such as different codon usage preferences. ${ }^{148}$ The evolution of decreased fitness costs, along with evolution of increased conjugation efficiencies, might explain the widespread occurrence of plasmids in natural bacterial communities irrespective of the presence of positive selection. ${ }^{149}$

Compared to AR mutations, AR plasmids are also subject to unique ecological phenomena. For instance, source-sink dynamics whereby a plasmid is transiently maintained in unsuitable hosts due to constant conjugative transfer from an abundant donor can enable wide access to plasmid-encoded ARGs in bacterial communities. ${ }^{150}$ Furthermore, a special feature of certain chromosomal or plasmid-located ARGs encoding antibiotic-inactivating enzymes is the capacity to confer resistance to surrounding cells. ${ }^{151}$ This enables, under the same level of selection, a higher proportion of plasmid-free cells in the population compared to ARGs conferring resistance only for the host cell. Conjugative plasmid carriage can also compromise the cell, since there are phages that infect hosts through plasmid-encoded pili..$^{152,153}$ All these phenomena affect the change in prevalence, transfer and particular selective pressures faced by, and therefore the fate of, plasmids and plasmid-encoded ARGs. Differences between antibiotic resistance caused by mutations or conjugative plasmids are summarized in Table 6. 
TABLE 6.

Differences between adaptive mutations and conjugative plasmids.

Feature

Adaptive mutation
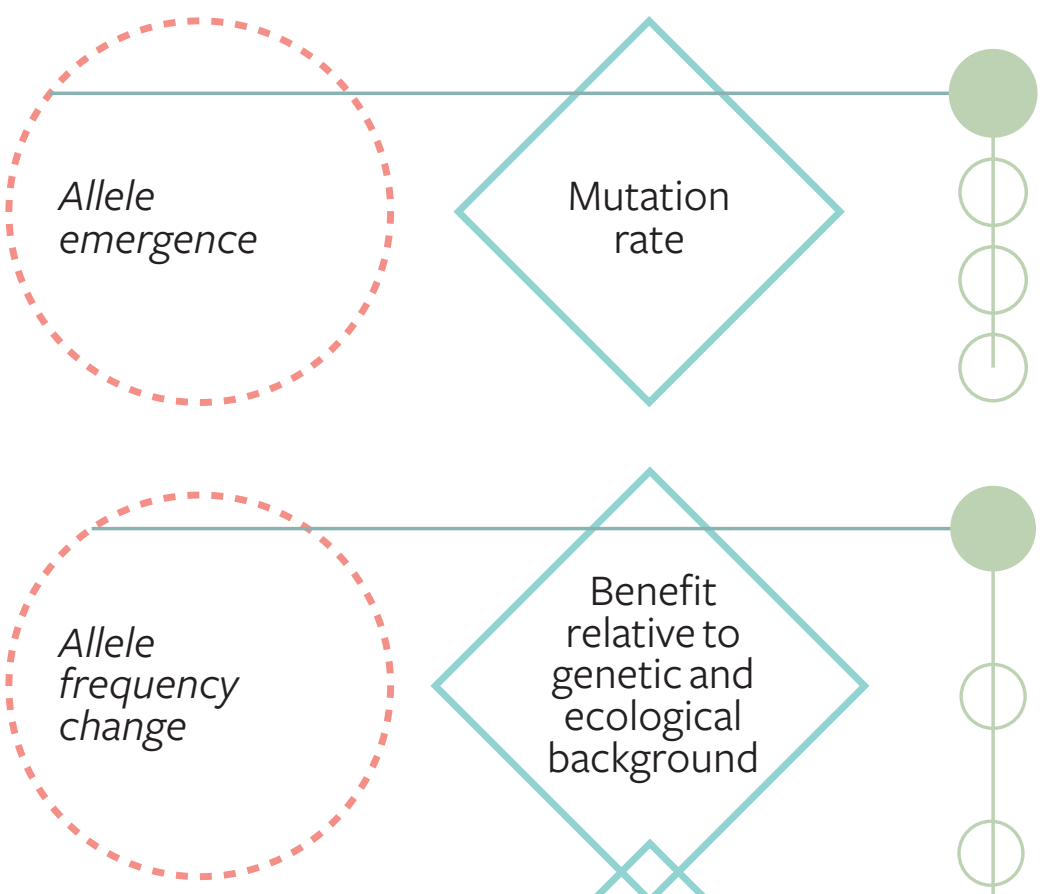
unlikely to be
Fixed

mutations

lost

Benefit relative to genetic and ecological background

Unlikely to increase without selection
Host suitability

Host encounter rate

Conjugation efficiency

Inhibition/induction factors

Benefit relative to genetic and ecological background

Conjugative plasmid

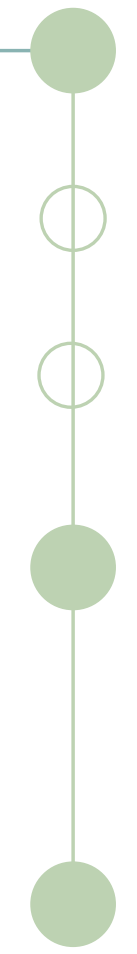

Conjugation efficiency

Segregation error rate

Potential to increase without selection

Potential to be lost despite 100\% prevalence 


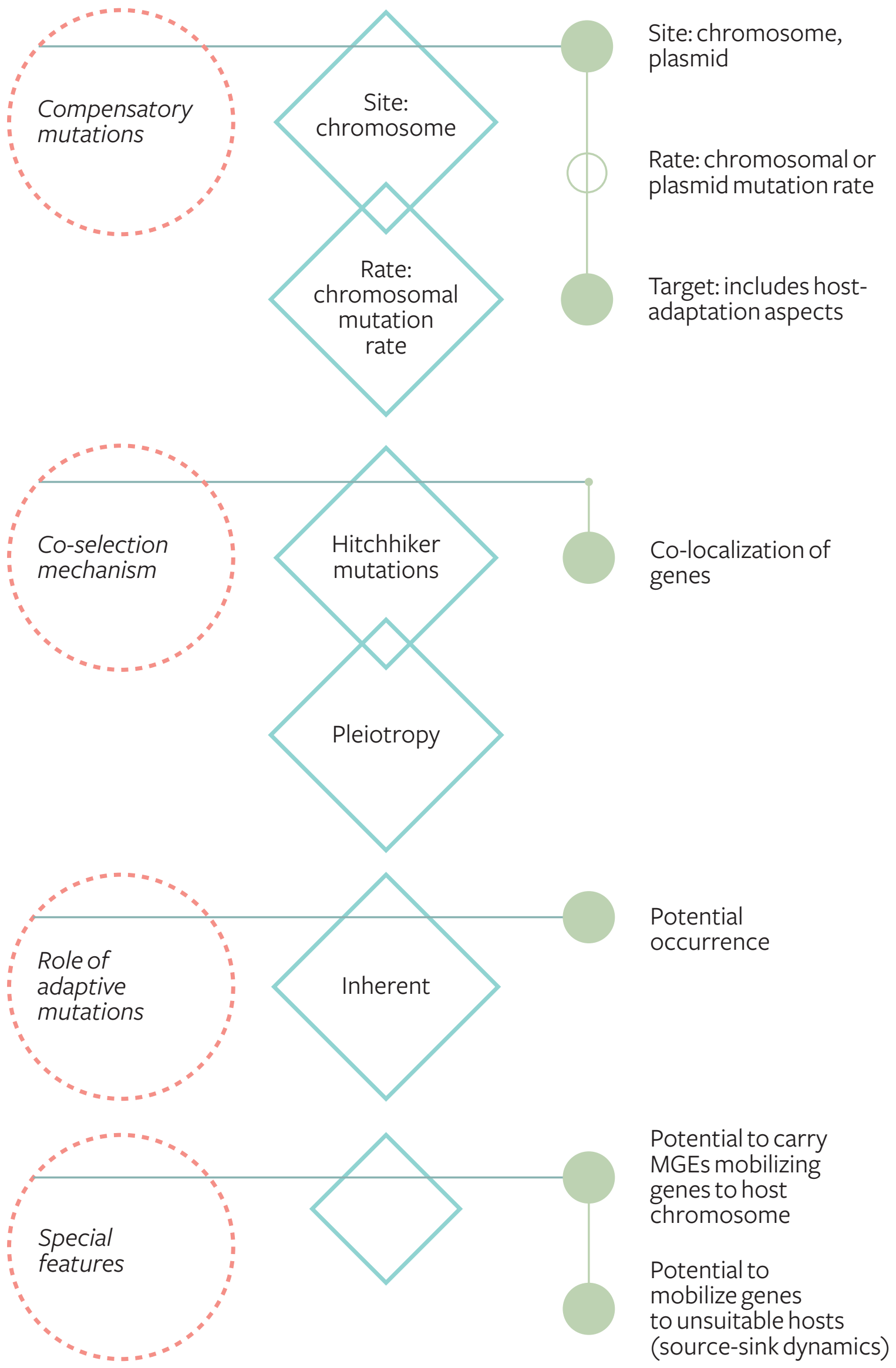


Importance of community context for how antibiotics affect bacteria

$\mathrm{O}$ ver the course of approximately 3.9 billion years ${ }^{154}$, evolutionary forces have produced tremendous biodiversity on Earth. Most of the species diversity is accounted for by microbes, including bacteria, archaea, viruses and unicellular eukaryotes. ${ }^{155,156}$ The most abundant entities are phages, the viruses of bacteria, which account for most of the $10^{31}$ viruses on Earth, followed by $10^{30}$ bacteria and archaea. ${ }^{157}$ Among the most abundant unicellular eukaryotes, bacterivorous protozoa occur at high densities in soil (e.g. $1.5 \times 10^{4}$ amoebae $\mathrm{g}^{-1}$ ) and aquatic environments (e.g. $10^{2}-10^{6}$ heterotrophic flagellates $\left.\mathrm{ml}^{-1}\right) \cdot{ }^{158}$ Bacteria $^{159}$, phages ${ }^{160}$, and protozoa $^{161}$ are also all abundant in the mammalian gut. Importantly, these organisms interact at a high rate, forming multispecies, multitrophic microbial communities. Because of their major role in bacterial ecology and evolution, the fate of AR mutations and HGT of ARGs are likely to be affected by the species interactions occurring in realistic community setting (Figure 4). ${ }^{162}$

In multispecies bacterial communities, niche differentiation and balancing selection can limit the strength and directionality of selection for AR mutations compared to a single species setting (see section 1.2.1 Adaptive resistance and Figures 2C-F). ${ }^{164,165}$ Overall, ecology can also be critical for the species involved in $\mathrm{HGT}^{163,164}$, although precise tracking of conjugative ARG plasmid transfer in multispecies settings has been hindered by methodological challenges ${ }^{165,166}$. Therefore, controlled testing of predictions concerning the effect of different antibiotic concentrations and other ecological factors on ARG plasmid transfer in complex communities is currently lacking. Furthermore, in multispecies settings, the effects of antibiotics can go beyond selection for AR mutations or promotion or inhibition of HGT of ARGs. The effect of antibiotics is determined by the resistance (insensitivity to disturbance) and resilience (rate of recovery after disturbance) of the community to disturbances. ${ }^{167,168} \mathrm{~A}$ sufficiently strong disturbance may result in a regime shift, denoting a persistent change in the structure or function of a community. ${ }^{169,170}$ Altered community composition and functioning can, in turn, impair ecosystems ${ }^{171}$ and health ${ }^{158,159}$. While high antibiotic concentrations cause strong changes in community composition and reduce diversity by driving susceptible species and genotypes to extinction, sub-MICs too can cause decreased diversity over the long term through increasing fitness variance ${ }^{172,173}$. However, the extent of the effect of sub-MICs relative to other key ecological factors, such as habitat structuring and trophic interactions, has received little attention prior to this thesis. ${ }^{174}$

\section{Effect of trophic interactions on antibiotic re- sistance evolution}

Prevalent trophic interactions with phage and protozoan consumers can also affect the ecology and evolution of antibiotic resistance. Consumers regulate bacterial population size and create strong selection for phage resistance ${ }^{175}$ and anti-predatory defense ${ }^{176}$ due to the death of susceptible cells. Antibiotic and phage resistance usually have different cellular mechanisms, evolving independently ${ }^{177}$. Under this scenario, the likelihood for a co-resistant double mutant to be present in a bacterial population upon exposure to both agents at lethal doses is very low (product of individual mutation probabilities). Therefore, a drastic crash occurs in the bacterial population, which might even go extinct. ${ }^{178}$ The bacterial population crash and associated prevention of antibiotic resistance evolution make phage-antibiotic combination therapies a promising alternative to single antibiotic, antibiotic combination (where resistances display more positive associations), and phage therapies in the medical context. ${ }^{177,179}$

Compared to high concentrations, the eco- 


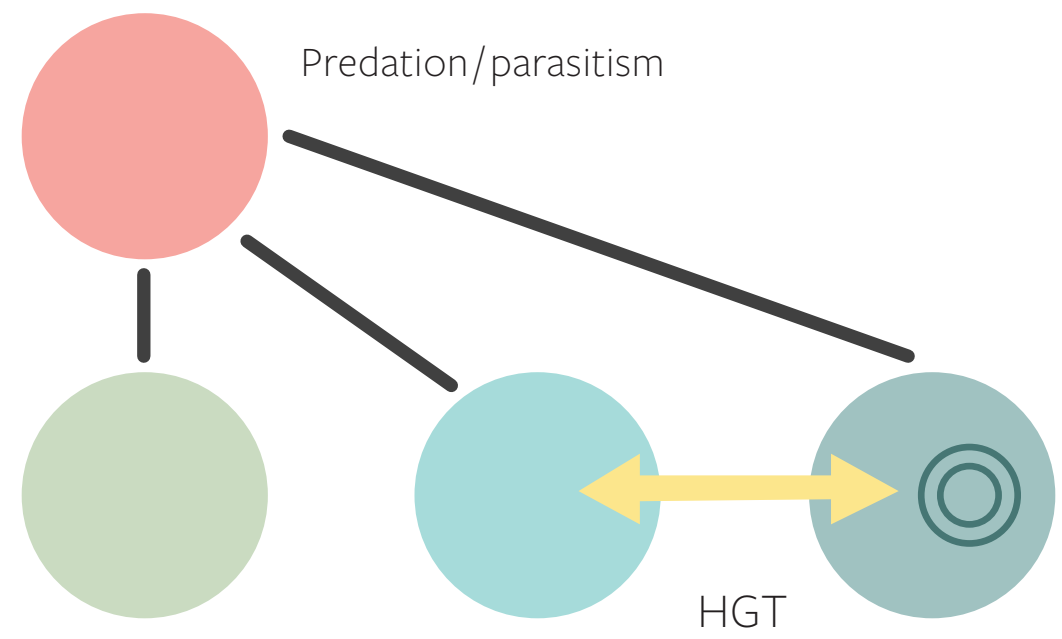

FIGURE 4 | Antibiotic resistance evolution occurs in communities of multiple bacterial species (green circles) that interact at a high rate with phage and protozoan consumers (red circle). Here, horizontal transfer of an antibiotic resistance plasmid (dark green) between two bacterial species is shown. Competitive interactions between species and trophic interactions with consumers (black lines) might affect the trajectories of antibiotic resistance mutations or horizontal transfer of resistance genes. This can occur through altered species abundance, cell physiology, or selective landscape. HGT = horizontal gene transfer. Original illustration courtesy of Teppo Hiltunen, re-rendered by No Jam Studio.

logical and evolutionary dynamics of bacterial populations co-exposed to phages and sub-MICs are less well understood. ${ }^{180}$ In this scenario, a weaker reduction in population size, primarily caused by the phage, is followed by recovery of a high population size. The bacterial population, now displaying high-frequency resistance to the phage, has recovered high mutation supply, enabling AR mutations to readily evolve against a phage resistant background. The combined fitness cost of phage and antibiotic resistance might, however, cause the requirement for stronger positive selection (i.e. higher antibiotic concentration) for co-resistant mutants to be selected, although this requirement might be removed by compensatory adaptations.

Current evidence suggests that phages limit conjugative plasmid mediated antibiotic resistance. In addition to decreased conjugation frequency as a result of population size reductions caused by phages, the combined cost of chromosomal phage resistance mutations and AR plasmid carriage can cause the requirement for stronger positive selection for plasmid maintenance. ${ }^{181}$ Furthermore, phages that infect the host through adsorbing to plasmid encoded pili select for conjugation-defective mutant plasmids, restricting the conjugative transfer of AR plasmids..$^{152}$

Compared to phages, the effect of protozoan predation on antibiotic resistance evolution has received little attention. However, although protozoa lack the therapeutic relevance of phages, their potential effect on AR mutations or plasmid transfer is non-trivial. In aquatic environments, which constitute $>90 \%$ of the biosphere, protozoan predation is often prevalent and can determine bacterial properties (Figure 5). ${ }^{182}$

Similar to phages, decreased bacterial population size and selection for anti-predatory defense mutations can decrease the rate of antibiotic resistance evolution under predation. This effect can be stronger for protozoa, which constantly regulate bacterial abundance compared to intermittent lysis by phages. In contrast, protozoa cause weaker selection for anti-predatory defense, since grazing removes a smaller fraction of susceptible bacteria. Compared to phages and antibiotics which have specific genomic targets of resistance mutations, protozoa might also select for mutations affecting 
more general traits such as cell aggregation (for different defense types, see ${ }^{182}$ ), decreasing effective prey population size or increasing prey handling time. ${ }^{183}$ Therefore, the mutations or mutational combinations causing increased levels of anti-predatory defense might be more numerous but possess smaller selection coefficients. Compared to phages, these factors can increase the likelihood of co-resistance and antibiotic resistance evolution under predation at super-MICs, while decreasing antibiotic resistance evolution through increasing the relative effect of interference interactions at sub-MICs. Protozoan abundances are also more even than phage abundances, and can maintain frequency dependent selection for defended and undefended prey genotypes. Under such a dynamic selective regime, AR genotypes might confer a lower fitness benefit at sub-MICs ${ }^{184}$, requiring higher concentrations for AR selection. Since cell aggregation causes both increased anti-predatory defense and increased antibiotic resistance ${ }^{183,185}$, pleiotropic mutations causing co-resistance might also be possible.

Protozoa can have variable effects on conjugative AR plasmid dynamics. Predation can inhibit plasmid transfer by reducing bacterial population size. ${ }^{186}$ Furthermore, the combined fitness cost of anti-predatory defense and plasmid carriage might decrease plasmid maintenance. Alternatively, predation might increase the frequency of plasmid conjugation by maintaining bacteria in an active growth state. The maintenance of bacteria under predation at a more active growth state has been demonstrated empirically ${ }^{187}$ and through modeling ${ }^{188}$. Owing to the importance of an active growth state to the expression of the conjugation machinery, a link between predation and increased conjugation activity was recently independently hypothesized by us (III) and another research group ${ }^{166}$. 


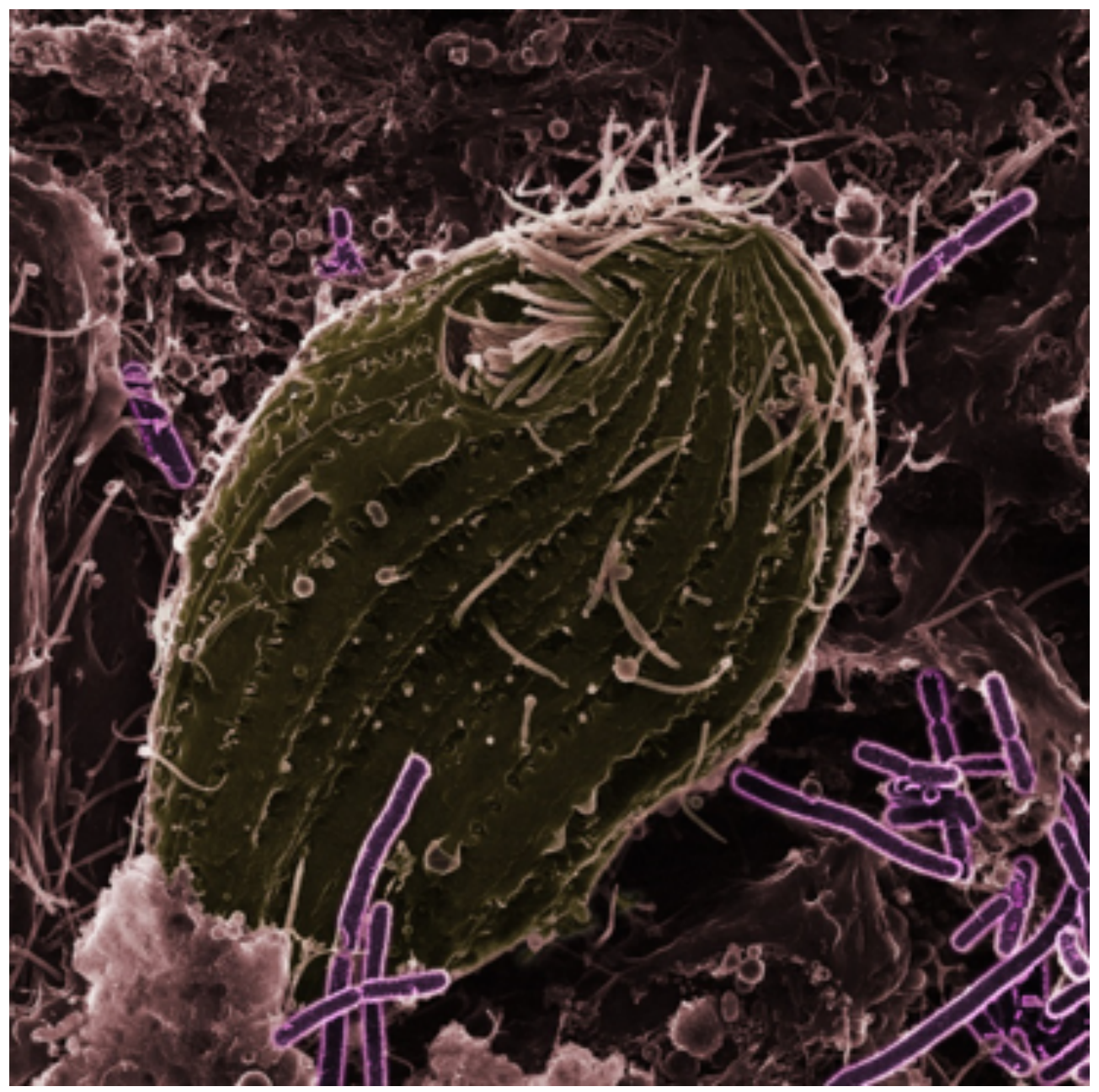

FIGURE 5 | Gram-negative bacteria (purple) predated by the ciliated protozoan Tetrahymena thermophila (green; proportions approx. $20 \times 50 \mu \mathrm{m}$ ).

Helium ion micrograph by Matti Jalasvuori. 


\section{AIMS OF THE THESIS}

y doctoral thesis investigated the interplay between sub-MICs of antibiotics, antibiotic resistance (via either mutations or horizontal gene transfer), and species interactions.

The specific aims of the thesis were:

- To study the effect of a virulent bacteriophage parasite and two sub-MICs of streptomycin on the evolution of a bacterial population using phenotypic assays (I) and whole-genome sequencing (II)

- To study the effect of a protozoan predator and sub-MIC of kanamycin on the spread and maintenance of a conjugative multidrug resistance plasmid in a bacterial population (III)

- To study the effect of a protozoan predator, sub-MIC of kanamycin and spatial structuring on community composition and the spread of a multidrug resistance plasmid in a multispecies bacterial community (IV) 


\section{SUMMARY OF MATERIAL AND METHODS}

T he methods and strains used in each study are explained in detail in the articles (I-IV) and their supplementary materials. A summary of the methods is presented in Table 7.

\section{TABLE 7.}

Methods used in this thesis. $\quad$ description
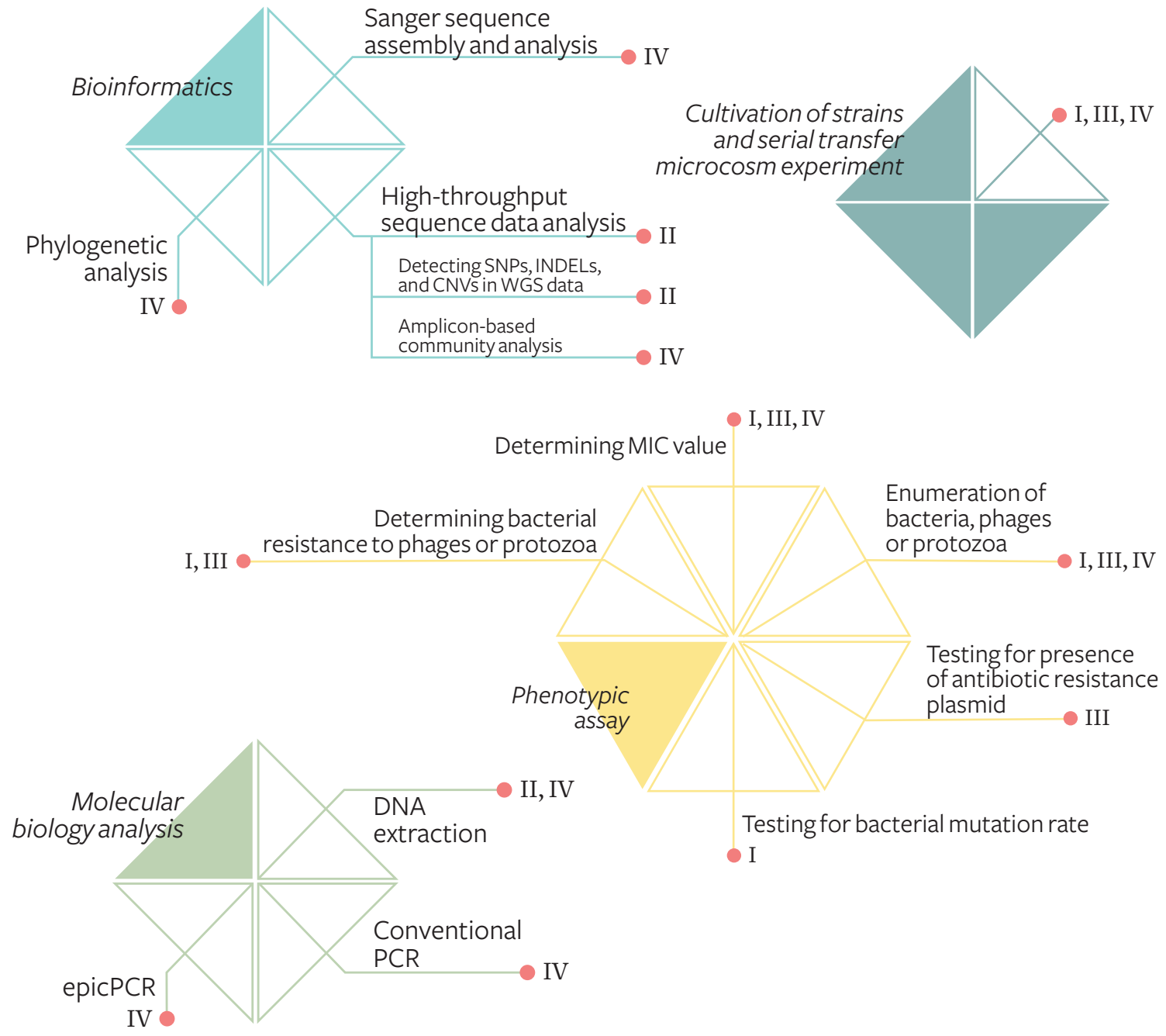



\section{SUMMARY OF RESULTS AND DISCUSSION}

\subsection{ADAPTIVE MUTATIONS UNDER SPECIES INTERACTIONS $(I, \mid$ II)}

$\mathrm{I}^{\mathrm{n}}$ $\mathrm{n}$ a bacterial population exposed to 0.01 or $0.1 \times$ MIC streptomycin over a 66-day evolutionary experiment, we found that AR phenotypes readily evolved in $0.1 \times$ MIC streptomycin (4/6 populations) irrespective of the presence of a phage (I). Streptomycin resistance was likely explained by mutations in the rpsL gene encoding the small subunit ribosomal RNA protein S12 previously shown to cause streptomycin resistance in bacteria (II; Figure 6). ${ }^{189}$ Furthermore, in 3/4 rpsL mutated populations, the mutations were fixed or near-fixed by the experimental end-point, suggesting that they confer strong fitness benefits unaffected by the evolutionary history of phage adaptation.

AR mutations were observed in $2 / 3$ replicate populations in both univariate and co-selected environments, while the experiment lacked power to detect potential sub-MIC effects that occur only in a subset of populations. Therefore, to further investigate the potential role of $0.1 \times$ MIC streptomycin on antibiotic resistance evolution, we conducted a 12-day experiment with four biological replicates (different bacterial colonies), each comprising 48 technical replicates (I). Here, we found that antibiotic resistance levels were higher in the 
presence of the phage compared to streptomycin alone. However, the genetic determinants accounting for these observations are unknown.

Similarly, contrary to predictions of decreased rates of adaptation in multivariate compared to univariate environments, in the 66-day experiment, we found higher levels of phage resistance phenotypes (I) and likely associated mutations (II) in bacteria under co-selection (Figure 6). Interestingly, this occurred despite a population size reduction in the presence of the phage and the antibiotic, predicted to further decrease adaptation through decreasing mutation supply. This outcome is even less expected since phage extinction should remove selection for phage resistance. The phage became extinct in the sub-MIC treatments by day $14 / 66$ and $40 / 66$ under $0.01 \times$ MIC and $0.1 \times$ MIC streptomycin, respectively, while remaining at a detectable level throughout the experiment in the absence of streptomycin. We also ruled out that these observations are caused by pleiotropic effects of antibiotic or phage resistance, as isolates from univariate environments with resistance phenotypes were not co-resistant (I: Supplementary materials), and the genetic resistance determinants were the same for co-selective and univariate environments (II; Figure 6). In line with these observations, the genomic data showed lack of clonal interference between antibiotic and phage resistance alleles, as they co-occurred in the same genomes under co-selection.

Together these results call into question the generality of decreased strength and directionality of selection under multiple selection pressures, which, however, was observed in the same system for bacteria and ciliates. ${ }^{184}$ Beyond pleiotropy, one proposed mechanism compensating for decreased strength of selection in multivariate environments is selection by one or several variables for mutators, i.e. strains with increased mutation rates caused, for example, by mutations in MMR genes. ${ }^{190,191 .}$ WGS analysis of the 66-day experiment end-point showed the presence of MMR mutants at high frequency in several populations, including $4 / 6$ of the co-selected populations, and lack of MMR mutants in the presence of phage alone (II; Figure 6). However, phage resistance mutations occurred at high frequency in the co-selection treatment also in the two populations lacking mutator alleles, and mutator alleles also occurred in the absence of either phage or streptomycin. This suggests that random distribution of mutator alleles across the experimental populations is unlikely to explain the observation of increased phage resistance under co-selection by chance, and that this is either in part or completely explained by other factors.

Sub-MICs of antibiotics can also be mutagenic, transiently increasing bacterial mutation rate, and thereby, potentially increasing the rate of adaptation to phages. In line with this, we found that sub-MICs of streptomycin increased the rate of bacterial mutation to phage resistance, although the effect was relatively weak (I). The effect of different antibiotics at sub-MICs on the rate of bacterial mutation to phage resistance was recently tested more extensively, with some similar, statistically significant results, although the effects were generally weak and inconsistent across different phages. ${ }^{178}$ Furthermore, in our experiment, the death of non-mutants in the fluctuation assay caused by streptomycin could have inflated mutant frequency, although this is unlikely, since the highest mutation rate was observed for the least inhibitory concentration $(0.01 \times \mathrm{MIC})$. New sophisticated approaches (implemented e.g. in the R package rSalvador ${ }^{192}$ ) have recently been developed for the determination of mutation rates, incorporating a larger number of potential sources of error.

The lack of clear associations between increased rates of adaptation under co-selection and either pleiotropy or inducible or evolved hypermutability suggests that there exist other population genetic or ecological mechanisms that can account for these observations. These include positive epistasis between phage and streptomycin resistance mutations ${ }^{193}$ and altered bacteria-phage co-evolutionary dynamics under streptomycin. ${ }^{175,194,195}$ Furthermore, while the population crash caused by a phage and lethal antibiotic concentrations ${ }^{178,196}$ necessitates the presence of rare co-resistant mutants for population survival, sub-MICs do not pose an immediate requirement for AR genotypes. Once the bacterial population recovers from phage exposure, containing a high prevalence of phage resistance genotypes, AR mutations are likely to emerge, and the sooner this occurs, the more likely AR mutations are to emerge against a phage resistant background. This might increase the likelihood for co-resistance evolution under sub-MICs. Alternatively or in addition, by increasing fitness 


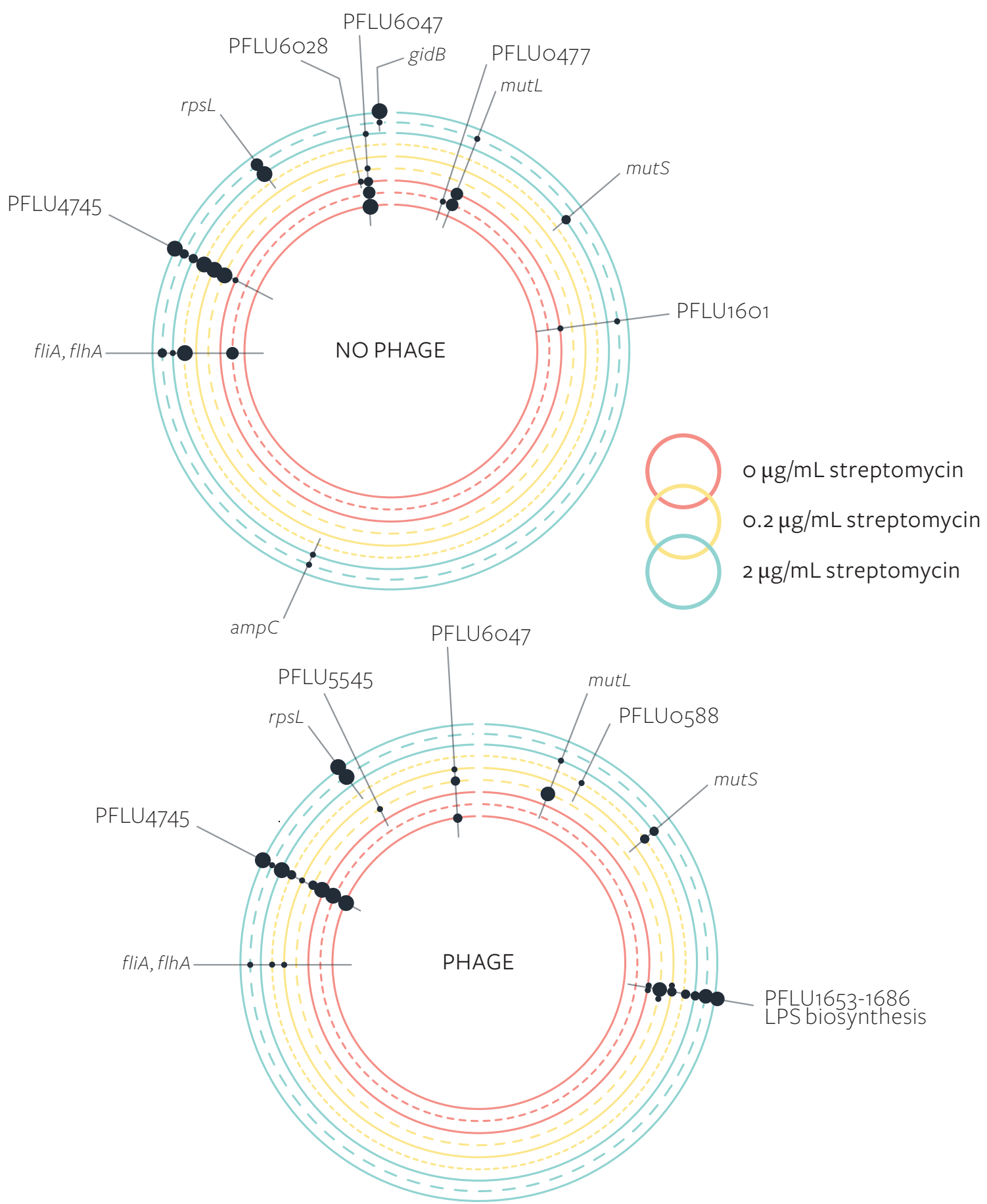

FIGURE 6 | Parallel evolution in experimental populations of Pseudomonas fluorescens SBW25 evolved for 66 days in the absence (top) or presence (bottom) of the phage SBW25 22 and absence or presence of one of two sub-MICs of streptomycin. 0.2 and $2 \mu \mathrm{g} \mathrm{ml}^{-1}$ represent 0.01 and $0.1 \times \mathrm{MIC}$, respectively. Mutations are indicated by dots, with the size of the dot representing the proportion of mutated genotypes in each population (min. 10\%, max. 100\%). Each concentric circle represents mutations along the chromosome in an individual bacterial population.. The phage appears to select for mutations in LPS biosynthesis genes (LPS is a known target of the phage), which, however, occur almost exclusively in the presence of streptomycin.

Reproduced from II with permission by John Wiley \& Sons, Inc, re-rendered by No Jam Studio. 
variance between genotypes ${ }^{172,173}$, sub-MICs of antibiotics might promote extinction of phage susceptible genotypes or increase the selection coefficient for AR mutations appearing in a costly phage resistant background, also increasing rates of resistance and co-resistance evolution. However, such dynamics cannot be reconstructed from our experimental end-point and warrant further investigation (for discussion of selection inference from single time point sequence data, see ${ }^{197}$ ).

\subsection{PLASMID TRANSFER UNDER SPECIESINTERACTIONS (III, IV)}

$\mathrm{E}$ xposure of a bacterial population harboring a multidrug resistance plasmid to $0.1 \times$ MIC kanamycin resulted in a decreased rate of kanamycin-resistance encoding $\mathrm{RP} 4$ plasmid loss over 60 days (III: Figure 7). This demonstrates that the sub-MIC used compensated for the fitness cost of plasmid carriage although not sufficiently to allow for plasmid maintenance in the long term. Notably, a conjugative version of the plasmid was lost more readily than its conjugation-defective counterpart. This suggests that active conjugation exerts a larger fitness cost to the host cell compared to plasmid maintenance alone, and therefore requires stronger positive selection for the plasmid to be maintained in the bacterial population. Interestingly, this scenario was reversed under predation by a ciliated protozoan: The conjugation-defective plasmid was lost while the conjugative plasmid was maintained at close to $100 \%$ prevalence. Importantly, this was unaffected by the presence of positive selection. Therefore, the ecological effect of protozoan predation alone was sufficient to maintain the plasmid in the population through promotion of conjugative transfer, counteracting negative selection against the plasmid imposed by fitness costs.

We separately demonstrated that the proportion of transconjugants increased under predation (III: Supplementary materials). We also showed that these effects were caused by the presence of live protozoa rather than compounds released from the protozoa (III: Supplementary materials).

Increased conjugation under predation is likely explained by maintenance of bacteria in an active, non-stationary growth phase, demonstrated for protozoan predation ${ }^{187,188}$ and required for expression of the conjugation machinery ${ }^{137,198}$. This effect of predation has been independently hypothesized by another research group ${ }^{166}$ and, subsequent to our study, a similar outcome was reported by Bien and colleagues for a different conjugative ARG plasmid under grazing by taxonomically and physiologically diverse protozoa. ${ }^{199}$ Higher metabolic activity of bacteria under predation has also been demonstrated in the laboratory, supporting the mechanistic hypothesis. ${ }^{200}$ Furthermore, the conjugation-promoting effect of ciliates has been shown to be strong enough to reverse near-loss of the plasmid following exposure to the conjugative plasmid dependent bacteriophage PRD1. ${ }^{200}$ Together these observations demonstrate that protozoa can promote plasmid maintenance in aquatic environments under a variety of conditions, although this requires further exploration in natural systems. An alternative mechanism by which predation can facilitate HGT of ARGs is through the release of DNA from consumed cells to the environment, where it can be acquired by bacteria through natural transformation. ${ }^{199,201}$

We also tested for the effect of protozoan predation, structured environment and low kanamycin concentration (approx. $6 \%$ of mean MIC value of strains) on the transfer of the RP4 plasmid from one donor strain in a 62-strain artificial bacterial community over 40 days (IV). The structured environment was created by adding glass beads to culture vials to allow formation of a complex biofilm matrix. Although the method used (epicPCR ${ }^{165}$ ) could not quantify the prevalence of 


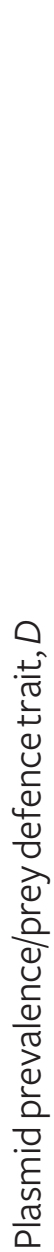

(a)

(c)
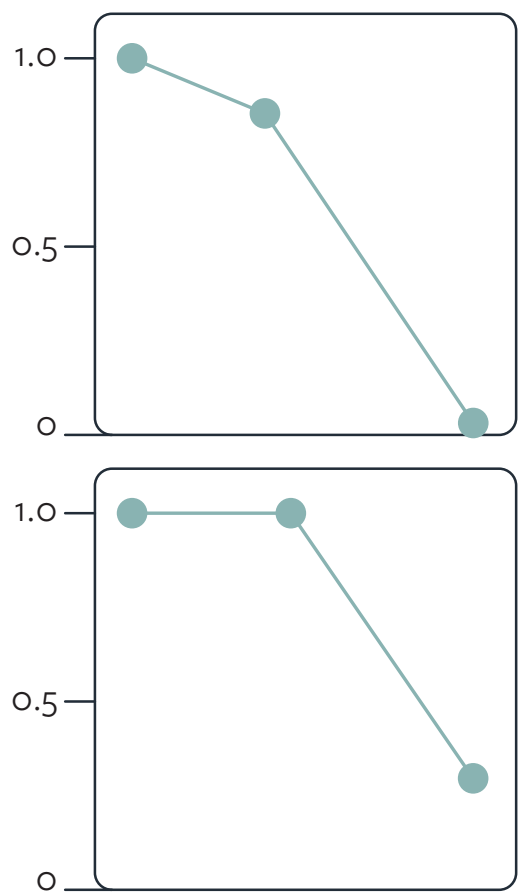

(e)

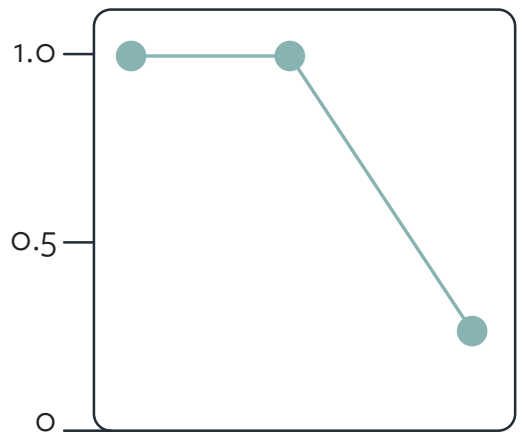

(g)

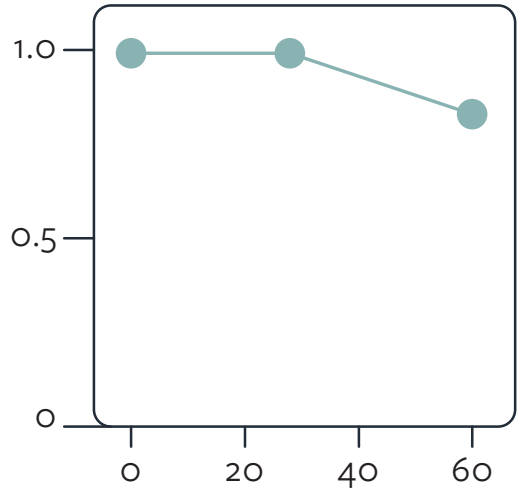

(b)

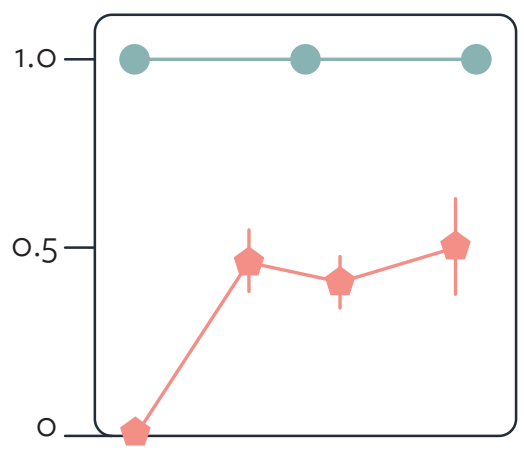

(d)

(f)
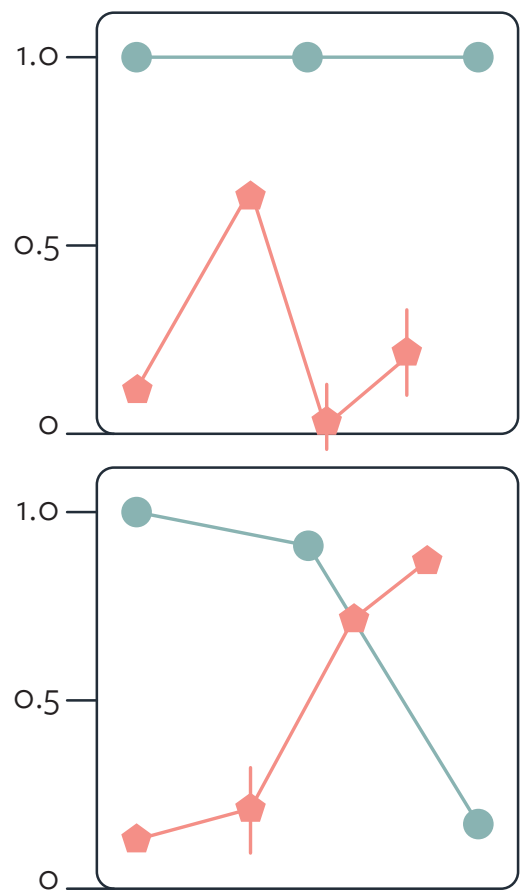

(h)

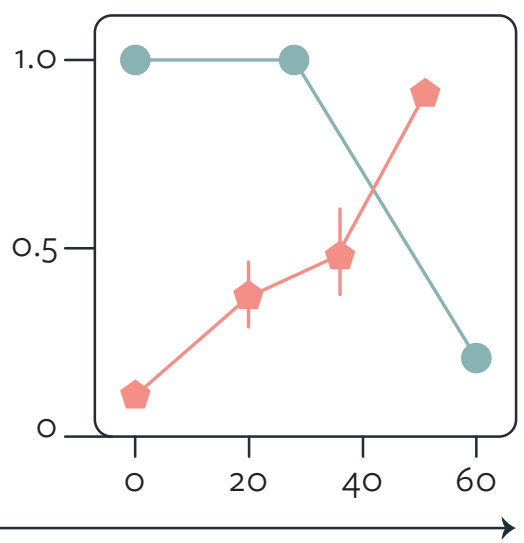

Time (days)

\section{_ plasmid}

\section{prey defense}

FIGURE 7 | Prevalence of conjugative and conjugation-defective RP4 plasmid and evolution in prey defense trait, $D$, over time (III; mean \pm s.e.). (A-D) The conjugative plasmid in kanamycin-free environment without (A) or with (B) predators, and in $0.1 \times$ MIC kanamycin without $(\mathbf{C})$ or with $(\mathbf{D})$ predators. (E-H) Conjugation-defective plasmid in kanamycin-free environment without $(\mathbf{E})$ or with $(\mathbf{F})$ predators, and in $0.1 \times$ MIC kanamycin without $(\mathbf{G})$ or with $(\mathbf{H})$ predators. 


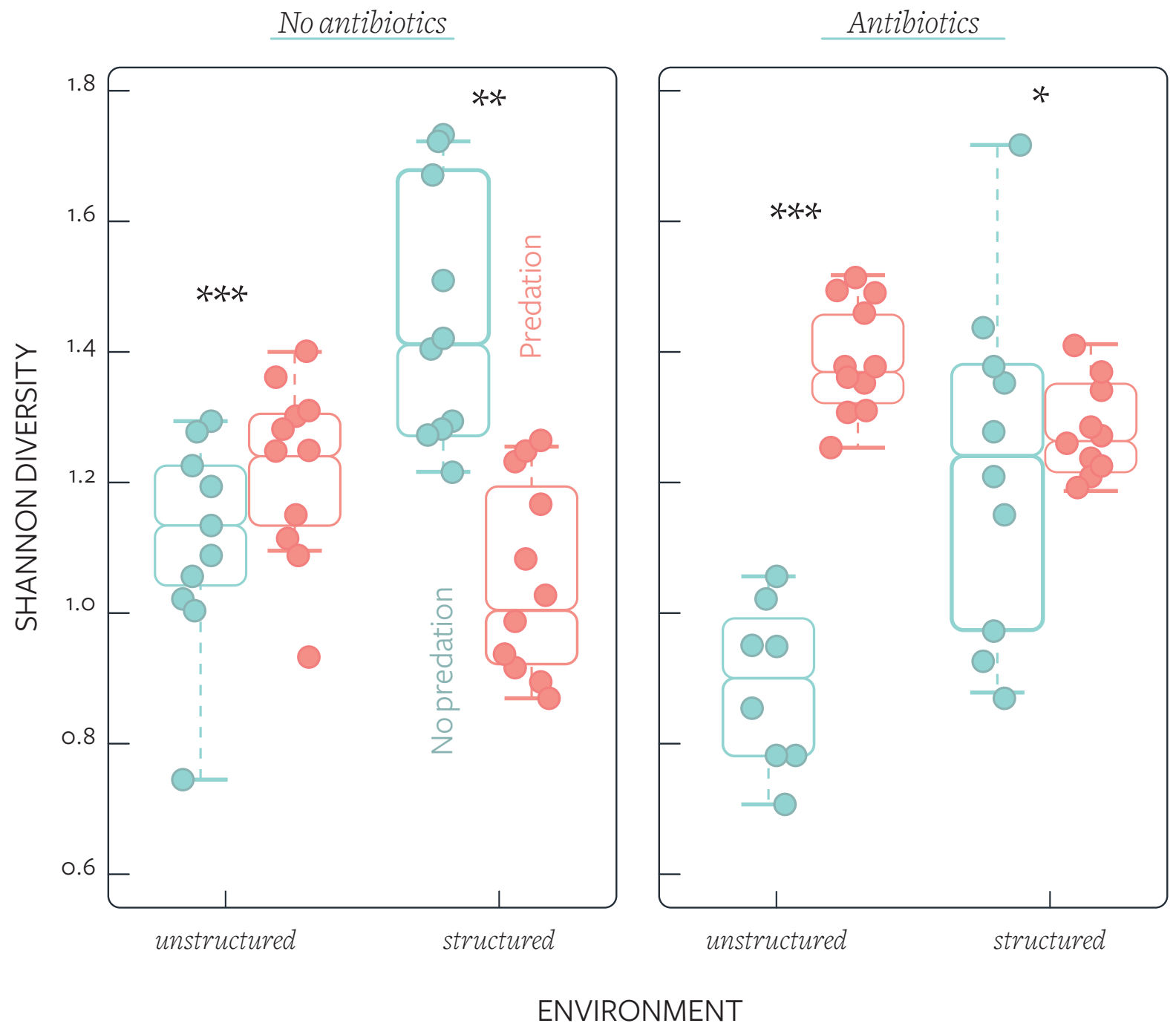

FIGURE 8 | The effect of antibiotic on species diversity (Shannon's index) depends on the presence of predation and spatial structuring (IV). 
plasmid recipients, we detected the presence of plasmid recipients across treatments among over a third of the taxa present at the experimental end-point. This shows the capacity of a broad host range plasmid to spread through a community under different ecological scenarios. ${ }^{111}$ Plasmid recipient profiles differed between treatments, supporting a key role for ecology in structuring HGT networks. ${ }^{163,164}$ The number of plasmid recipient taxa was higher under sub-MIC antibiotic. This could be caused by the antibiotic favoring taxa more likely to uptake or transfer the plasmid, as the antibiotic treatment was positively associated with the MIC value and growth rate of the strain. Alternatively, the antibiotic might have created selection for transconjugants. ${ }^{137}$ The likelihood of receiving the plasmid was coupled strongly with strain abundance, but this relationship was weakened in the presence of spatial structures. This could result from increased cell-to-cell contact and stability of Mpf in biofilms compared to well-mixed aqueous environments. ${ }^{136}$

These studies suggest that sub-MICs of antibiotics can promote ARG plasmid maintenance and might select for transconjugants in microbial communities. Moreover, key ecological factors, here protozoan predation and structuring of habitat, are implicated in enhancement of acquired antibiotic resistance. This is hypothesized to be an indirect consequence of altered physiological or physicochemical parameters affecting plasmid conjugation.

\subsection{COMMUNITY COMPOSITIONUNDERLOW CONCENTRATIONS (IV)}

$\mathrm{I}^{\mathrm{n}}$ $n$ the 40-day experiment with a 62-strain artificial bacterial community, a low kanamycin concentration had a strong effect on community composition (IV). Furthermore, the antibiotic caused reduced diversity in the unstructured environment but not in the structured environment (Figure 8). These observations support the notion that low antibiotic concentrations can reduce the diversity of bacterial communities ${ }^{172,173}$, although this effect is less likely to occur in structured environments where bacteria can display higher levels of antibiotic resistance ${ }^{185}$. Importantly, the presence of other ecological factors (protozoan predation or spatial structures), which had strong community effects on their own, strongly altered the effect of the antibiotic. For instance, predation reversed the diversity-decreasing effect of the antibiotic (Figure 8). This suggests that the community-level effects of sub-MICs of antibiotics can be weaker or comparable to the effects of other key ecological factors. This emphasizes the need to incorporate the ecological context to predictions concerning the community-wide effects of sub-MIC levels of antibiotics. 



\section{CONCLUSIONS AND PROSPECTS}

$I^{n}$ $\mathrm{n}$ this thesis, I investigated the effect of low antibiotic concentrations on adaptive and acquired antibiotic resistance in microbial communities. Antibiotic resistance was shown to be promoted by low antibiotic concentrations or other ecological factors in communities, uninhibited by the presence of ecological interactions. First, the resistance evolutionary potential of bacteria under low antibiotic concentrations was either unaffected or enhanced by the presence of phage parasitism. Second, protozoan predation maintained a conjugative resistance plasmid in a bacterial population irrespective of the presence of antibiotic selection. Third, the number of bacterial taxa that received a resistance plasmid in a multispecies community was higher under selection by a low antibiotic concentration. Moreover, lower species abundance was required for resistance plasmid uptake in a spatially structured environment.

The findings in my thesis show that low antibiotic concentrations occurring in human-impacted environments or the healthcare setting can promote antibiotic resistance evolution despite ecological complexity. Furthermore, they demonstrate the potential of realistic ecological settings to maintain antibiotic resistance genes even in the absence of selection. These findings emphasize the need for strategies to manage the antibiotic resistance problem that include consideration of low concentrations. It is also important to consider the possibility that once selected, antibiotic resistance genes might not easily be lost from microbial communities. This stresses the importance of efforts to minimize further resistance evolution, infections and infection transmission as means of tackling the antibiotic resistance crisis in addition to measures taken to reduce the prevalence of current resistance determinants.

The evolution of antibiotic resistance is promoted by a range of concentrations, including sub-MICs. To better understand the forces shaping antibiotic resistance evolution, continued investigation into antibiotic resistance trajectories at different concentrations in realistic ecological scenarios is vital. 
1. Hall, B. G. \& Barlow, M. Evolution of the serine $\beta$-lactamases: past, present and future. Drug Resist Updat 7, 111-123, doi:10.1016/j. drup.2004.02.003 (2004).

2. Baltz, R. H. Renaissance in antibacterial discovery from actinomycetes. Curr Opin Pharmacol 8, 557563, doi:10.1016/j.coph.2008.04.008 (2008).

3. Fajardo, A., Linares, J. F. \& Martínez, J. L. Towards an ecological approach to antibiotics and antibiotic resistance genes. Clin Microbiol Infect 15 Suppl 1, 14-16, doi:10.1111/j.14690691.2008.02688.x (2009).

4. Tong, L., Li, P., Wang, Y. \& Zhu, K. Analysis of veterinary antibiotic residues in swine wastewater and environmental water samples using optimized SPE-LC/MS/MS. Chemosphere 74, 1090-1097, doi:10.1016/j. chemosphere.2008.10.051 (2009).

5. Hernández, F., Sancho, J. V., Ibáñez, M. \& Guerrero, C. Antibiotic residue determination in environmental waters by LC-MS. Trends Analyt Chem 26, 466-485, doi:10.1016/j. trac.2007.01.012 (2007).

6. Ok, Y. S. et al. Monitoring of selected veterinary antibiotics in environmental compartments near a composting facility in Gangwon Province, Korea. Environ Monit Assess 174, 693-701, doi:10.1007/ 
S10661-010-1625-y (2011).

7. Davies, J. Are antibiotics naturally antibiotics? J Ind Microbiol Biotechnol 33, 496-499, doi:10.1007/s10295-006-0112-5 (2006).

8. Romero, D., Traxler, M. F., López, D. \& Kolter, R. Antibiotics as signal molecules. Chem Rev 111, 5492-5505, doi:10.1021/ cr2000509 (2011).

9. Bosch, F. \& Rosich, L. The contributions of Paul Ehrlich to pharmacology: a tribute on the occasion of the centenary of his Nobel Prize. Pharmacology 82, 171-179, doi:10.1159/000149583 (2008).

10. Fleming, A. On the antibacterial action of cultures of a penicillium with special reference to their use in the isolation of B. influenzae. Br J Exp Pathol 10, 226-236 (1929).

11. Seiple, I. B. et al. A platform for the discovery of new macrolide antibiotics. Nature 533, 338-345, doi:10.1038/nature17967 (2016).

12. Gustafson, R. H. \& Bowen, R. E. Antibiotic use in animal agriculture. J Appl Microbiol 83, 531-541, doi:10.1046/j.13652672.1997.00280.x (1997).

13. Hollis, A. \& Ahmed, Z. Preserving antibiotics, rationally. $N$ Engl J Med 369, 2474-2476, doi:10.1056/NEJMp1311479 (2013).

14. ECDC (European Centre for Disease Prevention and Control), EFSA (European Food Safety Authority) and European Medicines Agency. ECDC/EFSA/EMA first joint report on the integrated analysis of the consumption of antimicrobial agents and occurrence of antimicrobial resistance in bacteria from humans and food-producing animals. EFSA $J \mathbf{1 3}$, 4006, doi:10.2903/j.efsa.2015.4006 (2015).

15. Van Boeckel, T. P. et al. Global trends in antimicrobial use in food animals. Proc Natl Acad Sci U S A 112, 5649-5654, doi:10.1073/pnas.1503141112 (2015).

16. Hamad, B. The antibiotics market. Nat Rev Drug Discov 9, 675-676, doi:10.1038/nrd3267 (2010). 
17. Huttner, A., Harbarth, S., Hope, W. W., Lipman, J. \& Roberts, J. A. Therapeutic drug monitoring of the $\beta$-lactam antibiotics: what is the evidence and which patients should we be using it for? J Antimicrob Chemother 70, 3178-3183, doi:10.1093/ $\mathrm{jac} / \mathrm{dkv} 2 \mathrm{O} 1$ (2015).

18. Founou, L. L., Founou, R. C. \& Essack, S. Y. Antibiotic resistance in the food chain: A developing country-perspective. Front Microbiol 7, 1881, doi:10.3389/fmicb.2016.01881 (2016).

19. One Health approach to tackle antimicrobial resistance in South East Asia. BMJ 358, j3625, doi:10.1136/bmj.j3625 (2017).

20. Levison, M. E. \& Levison, J. H. Pharmacokinetics and pharmacodynamics of antibacterial agents. Infect Dis Clin North Am 23, 791-815, doi:10.1016/j.idc.2009.06.008 (2009).

21. Andersson, D. I. \& Hughes, D. Microbiological effects of sublethal levels of antibiotics. Nat Rev Microbiol 12, 465-478, doi:10.1038/nrmicro3270 (2014).

22. Larsson, D. G. J. Pollution from drug manufacturing: review and perspectives. Philos Trans R Soc Lond B Biol Sci 369, doi:10.1098/rstb.2013.0571 (2014).

23. Lundborg, C. S. \& Tamhankar, A. Antibiotic residues in the environment of South East Asia. BMJ 358, 42-45, doi:10.1136/ bmj.j2440 (2017).

24. Chen, Y. S., Zhang, H. B., Luo, Y. M. \& Song, J. Occurrence and assessment of veterinary antibiotics in swine manures: A case study in East China. Sci Bull 57, 606-614, doi:10.1007/ 
S11434-011-4830-3 (2012).

25. He, L. Y. et al. Discharge of swine wastes risks water quality and food safety: Antibiotics and antibiotic resistance genes from swine sources to the receiving environments. Environ Int 92-93, 210-219, doi:10.1016/j.envint.2016.03.023 (2016).

26. Senta, I., Terzic, S. \& Ahel, M. Occurrence and fate of dissolved and particulate antimicrobials in municipal wastewater treatment. Water Res 47, 705-714, doi:10.1016/j. watres.2012.10.041 (2013).

27. Larsson, D. G. J. Antibiotics in the environment. Ups J Med Sci 119, 108-112, doi:10.3109/03009734.2014.896438 (2014).

28. D'Costa, V. M. et al. Antibiotic resistance is ancient. Nature 477, 457-461, doi:10.1038/nature10388 (2011).

29. Pawlowski, A. C. et al. A diverse intrinsic antibiotic resistome from a cave bacterium. Nat Commun 7, 13803, doi:10.1038/ ncomms13803 (2016).

30. Aarestrup, F. M. Veterinary drug usage and antimicrobial resistance in bacteria of animal origin. Basic Clin Pharmacol Toxicol 96, 271-281, doi:10.1111/j.1742-7843.2005.pto960401.x (2005).

31. Chantziaras, I., Boyen, F., Callens, B. \& Dewulf, J. Correlation between veterinary antimicrobial use and antimicrobial resistance in food-producing animals: a report on seven countries. J Antimicrob Chemother 69, 827-834, doi:10.1093/jac/ dkt443 (2014). 
32. McLaughlin, M. et al. Correlations of antibiotic use and carbapenem resistance in Enterobacteriaceae. Antimicrob Agents Chemother 57, 5131-5133, doi:10.1128/Aac.00607-13 (2013).

33. Goossens, H., Ferech, M., Stichele, R. V., Elseviers, M. \& ESAC Project Group. Outpatient antibiotic use in Europe and association with resistance: a cross-national database study. Lancet 365, 579-587, doi:10.1016/So140-6736(05)17907-o (2005).

34. ECDC (European Centre for Disease Prevention and Control), EFSA (European Food Safety Authority) and European Medicines Agency. ECDC/EFSA/EMA second joint report on the integrated analysis of the consumption of antimicrobial agents and occurrence of antimicrobial resistance in bacteria from humans and food-producing animals - joint interagency antimicrobial consumption and resistance analysis (JIACRA) report. EFSA J 15, e04872, doi:10.2903/j.efsa.2017.4872 (2017).

35. Knapp, C. W., Dolfing, J., Ehlert, P. A. I. \& Graham, D. W. Evidence of increasing antibiotic resistance gene abundances in archived soils since 1940. Environ Sci Technol 44, 580-587, doi:10.1021/es901221x (2010).

36. Muurinen, J. et al. Influence of manure application on the environmental resistome under finnish agricultural practice with restricted antibiotic use. Environ Sci Technol 51, 59895999, doi:10.1021/acs.est7boo551 (2017).

37. Phillips, I. et al. Does the use of antibiotics in food animals 
pose a risk to human health? A reply to critics. J Antimicrob Chemother 54, 276-278, doi:10.1093/jac/dkh262 (2004).

38. Vieira, A. R. et al. Association between antimicrobial resistance in Escherichia coli isolates from food animals and blood stream isolates from humans in Europe: An ecological study. Foodborne Pathog Dis 8, 1295-1301, doi:10.1089/fpd.2011.0950 (2011).

39. Price, L. B. et al. Staphylococcus aureus CC398: Host adaptation and emergence of methicillin resistance in livestock. MBio 4, eoo305-11, doi:10.1128/mBio.00305-11 (2012).

40. Wellington, E. M. H. et al. The role of the natural environment in the emergence of antibiotic resistance in gram-negative bacteria. Lancet Infect Dis 13, 155-165, doi:10.1016/S14733099(12)70317-1 (2013).

41. Boucher, H. W. et al. Bad bugs, no drugs: no ESKAPE! An update from the Infectious Diseases Society of America. Clin Infect Dis 48, 1-12, doi:10.1086/595011 (2009).

42. Davies, J. \& Davies, D. Origins and evolution of antibiotic resistance. Microbiol Mol Biol Rev 74, 417-433, doi:10.1128/ Mmbr.00016-10 (2010).

43. Sekyere, J. O. Current state of resistance to antibiotics of last-resort in South Africa: A review from a public health perspective. Front Public Health 4, 209, doi:10.3389/ fpubh.2016.00209 (2016).

44. Kantele, A. et al. Antimicrobials increase travelers' risk of col- 
onization by extended-spectrum betalactamase-producing Enterobacteriaceae. Clin Infect Dis 60, 837-846, doi:10.1093/ cid/ciu957 (2015).

45. Projan, S. J. Why is big Pharma getting out of antibacterial drug discovery? Curr Opin Microbiol 6, 427-430, doi:10.1016/j. mib.2003.08.003 (2003).

46. Bengtsson-Palme, J., Gunnarsson, L. \& Larsson, D. G. J. Can branding and price of pharmaceuticals guide informed choices towards improved pollution control during manufacturing? J Clean Prod 171, 137-146, doi:10.1016/j.jclepro.2017.09.247 (2018).

47. Gudiol, C. \& Carratalà, J. Antibiotic resistance in cancer patients. Expert Rev Anti Infect Ther 12, 1003-1016, doi:10.1586/1 4787210.2014.920253 (2014).

48. Yoshikawa, T. T. Antimicrobial resistance and aging: Beginning of the end of the antibiotic era? J Am Geriatr Soc 50, S226-S229 (2002).

49. Martens, E. \& Demain, A. L. The antibiotic resistance crisis, with a focus on the United States. J Antibiot (Tokyo) 70, 520526, doi:10.1038/ja.2017.30 (2017).

50. Centers for Disease Control and Prevention (CDC). Antibiotic/antimicrobial resistance. https://www.cdc.gov/drugresistance/ (accessed 12 January 2018).

51. European Road Safety Observatory (ERSO). Annual accident report 2017. https://www.erso.eu/ (accessed 13 Febru- 
ary 2018).

52. de Kraker, M. E. A., Stewardson, A. J. \& Harbarth, S. Will 10 million people die a year due to antimicrobial resistance by 2050? PLoS Med 13, e1002184, doi:10.1371/journal. pmed.1002184(2016).

53. Cox, G. \& Wright, G. D. Intrinsic antibiotic resistance: Mechanisms, origins, challenges and solutions. Int J Med Microbiol 303, 287-292, doi:10.1016/j.ijmm.2013.02.009 (2013).

54. Blair, J. M., Webber, M. A., Baylay, A. J., Ogbolu, D. O. \& Piddock, L. J. Molecular mechanisms of antibiotic resistance. Nat Rev Microbiol 13, 42-51, doi:10.1038/nrmicro3380 (2015).

55. Sánchez, M. B. Antibiotic resistance in the opportunistic pathogen Stenotrophomonas maltophilia. Front Microbiol 6, 658, doi:10.3389/fmicb.2015.00658 (2015).

56. Koonin, E. V., Makarova, K. S. \& Aravind, L. Horizontal gene transfer in prokaryotes: quantification and classification. Annu Rev Microbiol 55, 709-742, doi:10.1146/annurev.micro.55.1.709 (2001).

57. Ochman, H., Lawrence, J. G. \& Groisman, E. A. Lateral gene transfer and the nature of bacterial innovation. Nature 405, 299-304, doi:10.1038/35012500 (2000).

58. Segerman, B. The genetic integrity of bacterial species: the core genome and the accessorygenome, two different stories. Front Cell Infect Microbiol 2, 116, doi:10.3389/fcimb.2012.00116 (2012). 
59. Perron, G. G., Lee, A. E., Wang, Y., Huang, W. E. \& Barraclough, T. G. Bacterial recombination promotes the evolution of multi-drug-resistance in functionally diverse populations. Proc Biol Sci 279, 1477-1484, doi:10.1098/rspb.2011.1933 (2012).

6o. Drake, J. W., Charlesworth, B., Charlesworth, D. \& Crow, J. F. Rates of spontaneous mutation. Genetics 148, 1667-1686 (1998).

61. Denamur, E. \& Matic, I. Evolution of mutation rates in bacteria. Mol Microbiol 60, 820-827, doi:10.1111/j.13652958.2006.05150.x (2006).

62. Žgur-Bertok, D. DNA damage repair and bacterial pathogens. PLoS Pathog 9, e1003711, doi:10.1371/journal.ppat.1003711 (2013).

63. Bryant, J., Chewapreecha, C. \& Bentley, S. D. Developing insights into the mechanisms of evolution of bacterial pathogens from whole-genome sequences. Future Microbiol 7, 1283-1296, doi:10.2217/Fmb.12.108 (2012).

64. Agashe, D. et al. Large-effect beneficial synonymous mutations mediate rapid and parallel adaptation in a bacterium. Mol Biol Evol 33, 1542-1553, doi:10.1093/molbev/mswo35 (2016).

65. Quax, T. E. F., Claassens, N. J., Soll, D. \& van der Oost, J. Codon bias as a means to fine-tune gene expression. Mol Cell 59, 149-161, doi:10.1016/j.molcel.2015.05.035 (2015). 
66. MacLean, R. C. \& Buckling, A. The distribution of fitness effects of beneficial mutations in Pseudomonas aeruginosa. PLoS Genet 5, e1000406, doi:10.1371/journal.pgen.1000406 (2009).

67. Hall, A. R., Iles, J. C. \& MacLean, R. C. The fitness cost of rifampicin resistance in Pseudomonas aeruginosa depends on demand for RNA Polymerase. Genetics 187, 817-822, doi:10.1534/genetics.110.124628 (2011).

68. Vogwill, T. \& MacLean, R. C. The genetic basis of the fitness costs of antimicrobial resistance: a meta-analysis approach. Evol Appl 8, 284-295, doi:10.1111/eva.12202 (2015).

69. Melnyk, A. H., Wong, A. \& Kassen, R. The fitness costs of antibiotic resistance mutations. Evol Appl 8, 273-283, doi:10.1111/ eva.12196 (2015).

70. Pietsch, F. et al. Ciprofloxacin selects for RNA polymerase mutations with pleiotropic antibiotic resistance effects. JAntimicrob Chemother 72, 75-84, doi:10.1093/jac/dkw364 (2017).

71. Sandegren, L. \& Andersson, D. I. Bacterial gene amplification: implications for the evolution of antibiotic resistance. Nat Rev Microbiol 7, 578-588, doi:10.1038/nrmicro2174 (2009).

72. Springer, B. et al. Mechanisms of streptomycin resistance: selection of mutations in the 16S rRNA gene conferring resistance. Antimicrob Agents Chemother 45, 2877-2884, doi:10.1128/AAC.45.10.2877-2884.2001 (2001).

73. Rybkine, T., Mainardi, J. L., Sougakoff, W., Collatz, E. \& Gut- 
mann, L. Penicillin-binding protein 5 sequence alterations in clinical isolates of Enterococcus faecium with different levels of beta-lactam resistance. J Infect Dis 178, 159-163 (1998).

74. Cui, L., Neoh, H. M., Shoji, M. \& Hiramatsu, K. Contribution of vraSR and graSR point mutations to vancomycin resistance in vancomycin-intermediate Staphylococcus aureus. Antimicrob Agents Chemother 53, 1231-1234, doi:10.1128/ AAC.01173-08 (2009).

75. Bagel, S., Hullen, V., Wiedemann, B. \& Heisig, P. Impact of gyrA and parC mutations on quinolone resistance, doubling time, and supercoiling degree of Escherichia coli. Antimicrob Agents Chemother 43, 868-875 (1999).

76. Aldred, K. J., Kerns, R. J. \& Osheroff, N. Mechanism of quinolone action and resistance. Biochemistry 53, 1565-1574, doi:10.1021/bi5000564 (2014).

77. Mariam, D. H., Mengistu, Y., Hoffner, S. E. \& Andersson, D. I. Effect of rpoB mutations conferring rifampin resistance on fitness of Mycobacterium tuberculosis. Antimicrob Agents Chemother 48, 1289-1294 (2004).

78. Hu, M., Nandi, S., Davies, C. \& Nicholas, R. A. High-level chromosomally mediated tetracycline resistance in Neisseria gonorrhoeae results from a point mutation in the rpsJ gene encoding ribosomal protein S1o in combination with the $m t r R$ and penB resistance determinants. Antimicrob Agents Chemother 49, 4327-4334, doi:10.1128/AAC.49.10.4327-4334.2005 
(2005).

79. Gullberg, E. et al. Selection of resistant bacteria at very low antibiotic concentrations. PLoS Pathog 7, e1002158, doi:10.1371/journal.ppat.1002158 (2011).

80. Bengtsson-Palme, J. \& Larsson, D. G. Concentrations of antibiotics predicted to select for resistant bacteria: Proposed limits for environmental regulation. Environ Int 86, 140-149, doi:10.1016/j.envint.2015.10.015 (2016).

81. Desai, M. M. \& Fisher, D. S. Beneficial mutation-selection balance and the effect of linkage on positive selection. Genetics 176, 1759-1798, doi:10.1534/genetics.106.067678 (2007).

82. Schiffels, S., Szollosi, G. J., Mustonen, V. \& Lassig, M. Emergent neutrality in adaptive asexual evolution. Genetics 189, 1361-1375, doi:10.1534/genetics.111.132027 (2011).

83. Good, B. H., Rouzine, I. M., Balick, D. J., Hallatschek, O. \& Desai, M. M. Distribution of fixed beneficial mutations and the rate of adaptation in asexual populations. Proc Natl Acad Sci U S A 109, 4950-4955, doi:10.1073/pnas.1119910109 (2012).

84. Maddamsetti, R., Lenski, R. E. \& Barrick, J. E. Adaptation, clonal interference, and frequency-dependent Interactions in a long-term evolution experiment with Escherichia coli. Genetics 200, 619-631, doi:10.1534/genetics.115.176677 (2015).

85. Ribeck, N. \& Lenski, R. E. Modeling and quantifying frequency-dependent fitness in microbial populations with cross-feeding interactions. Evolution 69, 1313-1320, 
doi:10.1111/evo.12645 (2015).

86. Marx, C. J. Can you sequence ecology? Metagenomics of adaptive diversification. PLoS Biol 11, e1001487, doi:10.1371/ journal.pbio.1001487 (2013).

87. Levin-Reisman, I. et al. Antibiotic tolerance facilitates the evolution of resistance. Science 355, 826-830, doi:10.1126/science.aaj2191 (2017).

88. Hughes, D. \& Andersson, D. I. Evolutionary consequences of drug resistance: shared principles across diverse targets and organisms. Nat Rev Genet 16, 459-471, doi:10.1038/nrg3922 (2015).

89. Wong, A. Epistasis and the evolution of antimicrobial resistance. Front Microbiol 8, 246, doi:10.3389/fmicb.2017.00246 (2017)

90. Mira, P. M., Meza, J. C., Nandipati, A. \& Barlow, M. Adaptive landscapes of resistance genes change as antibiotic concentrations change. Mol Biol Evol 32, 2707-2715, doi:10.1093/molbev/msv146 (2015).

91. Schultz zur Wiesch, P. S., Engelstädter, J. \& Bonhoeffer, S. Compensation of fitness costs and reversibility of antibiotic resistance mutations. Antimicrob Agents Chemother 54, 20852095, doi:10.1128/Aac.01460-09 (2010).

92. Hughes, D. \& Andersson, D. I. Evolutionary trajectories to antibiotic resistance. Аnnu Rev Microbiol 71, 579-596, doi:10.1146/annurev-micro-090816-093813 (2017). 
93. Bae, J., Oh, E. \& Jeon, B. Enhanced transmission of antibiotic resistance in Campylobacter jejuni biofilms by natural transformation. Antimicrob Agents Chemother 58, 7573-7575, doi:10.1128/Aac.04066-14 (2014).

94. Woo, P. C. Y., To, A. P. C., Lau, S. K. P. \& Yuen, K. Y. Facilitation of horizontal transfer of antimicrobial resistance by transformation of antibiotic-induced cell-wall-deficient bacteria. Med Hypotheses 61, 503-508, doi:10.1016/So3069877(03)00205-6 (2003).

95. Forterre, P., Da Cunha, V. \& Catchpole, R. Plasmid vesicles mimicking virions. Nat Microbiol 2, 1340-1341, doi:10.1038/ S41564-017-0032-3 (2017).

96. Domingues, S. \& Nielsen, K. M. Membrane vesicles and horizontal gene transfer in prokaryotes. Curr Opin Microbiol 38, 16-21, doi:10.1016/j.mib.2017.03.012 (2017).

97. Balcazar, J. L. Bacteriophages as vehicles for antibiotic resistance genes in the environment. PLoS Pathog 10, e1004219, doi:10.1371/journal.ppat.1004219 (2014).

98. Modi, S. R., Lee, H. H., Spina, C. S. \& Collins, J. J. Antibiotic treatment expands the resistance reservoir and ecological network of the phage metagenome. Nature 499, 219-222, doi:10.1038/nature12212 (2013).

99. Haaber, J. et al. Bacterial viruses enable their host to acquire antibiotic resistance genes from neighbouring cells. Nat Commun 7, 13333, doi:10.1038/ncomms13333 (2016). 
100. Bielaszewska, M. et al. Effects of antibiotics on shiga toxin 2 production and bacteriophage induction by epidemic Escherichia coli $\mathrm{O}_{104: \mathrm{H}_{4}}$ strain. Antimicrob Agents Chemother 56, 3277-3282, doi:10.1128/Aac.06315-11 (2012).

101. Carattoli, A. Plasmids and the spread of resistance. Int $J$ Med Microbiol 303, 298-304, doi:10.1016/j.ijmm.2013.02.001 (2013).

102. Pfeifer, Y., Cullik,A.\&Witte,W. Resistance to cephalosporins and carbapenems in Gram-negative bacterial pathogens. Int J Med Microbiol 300,371-379, doi:10.1016/j.ijmm.2010.04.005 (2010).

103. Werner, G., Klare, I. \& Witte, W. Large conjugative vanA plasmids in vancomycin-resistant Enterococcusfaecium. J Clin Microbiol 37, 2383-2384 (1999).

104. World Health Organization (WHO). Global priority list of antibiotic-resistant bacteria to guide research, discovery, and development of new antibiotics, 1-7, World Health Organisation (2017).

105. Nikaido,H.Multidrugresistanceinbacteria.AnnuRevBiochem 78, 119-146, doi:10.1146/annurev.biochem.78.082907.145923 (2009).

106. Bradford, P. A. Extended-spectrum $\beta$-lactamases in the 21st century: Characterization, epidemiology, and detection of this important resistance threat. Clin Microbiol Rev 14, 933951, doi:10.1128/Cmr.14.4.933-951.2001 (2001). 
107. San Millán, A., Heilbron, K. \& MacLean, R. C. Positive epistasis between co-infecting plasmids promotes plasmid survival in bacterial populations. ISME J 8, 601-612, doi:10.1038/ ismej.2013.182 (2014).

108. Johnson, C. M. \& Grossman, A. D. Integrative and conjugative Elements (ICEs): What they do and how they work. Annu Rev Genet 49, 577-601, doi:10.1146/annurev-genet-112414-055018 (2015).

109. Frost, L. S., Leplae, R., Summers, A. O. \& Toussaint, A. Mobile genetic elements: the agents of open source evolution. Nat Rev Microbiol 3, 722-732, doi:10.1038/nrmicro1235 (2005).

110. Garneau-Tsodikova, S. \& Labby, K. J. Mechanisms of resistance to aminoglycoside antibiotics: Overview and perspectives. Medchemcomm 7, 11-27, doi:10.1039/C5MDoo344J (2016).

111. Medeiros, A. A. $\beta$-lactamases: quality and resistance. Clin Microbiol Infect 3 Suppl 4, S2-S9 (1997).

112. Hegstad, K., Mikalsen, T., Coque, T. M., Werner, G. \& Sundsfjord, A. Mobile genetic elements and their contribution to the emergence of antimicrobial resistant Enterococcus faecalis and Enterococcus faecium. Clin Microbiol Infect 16, 541554, doi:10.1111/j.1469-0691.2010.03226.x (2010).

113. Munita, J. M. \& Arias, C. A. Mechanisms of antibiotic resistance. Microbiol Spectr 4, VMBF-oo16-2015, doi:10.1128/microbiolspec.VMBF-0016-2015 (2016). 
114. Jacoby, G. A., Strahilevitz, J. \& Hooper, D. C. Plasmid-mediated quinolone resistance. Microbiol Spectr 2, 10, doi:10.1128/ microbiolspec.PLAS-0006-2013 (2014).

115. Chandrasekaran, S. \& Lalithakumari, D. Plasmid-mediated rifampicin resistance in Pseudomonas fluorescens. J Med Microbiol 47, 197-200, doi:10.1099/00222615-47-3-197 (1998).

116. Dabbs, E. R. et al. Ribosylation by mycobacterial strains as a new mechanism of rifampin inactivation. Antimicrob Agents Chemother 39, 1007-1009, doi:10.1128/Aac.39.4.1007 (1995).

117. Speer, B. S., Shoemaker, N. B. \& Salyers, A. A. Bacterial resistance to tetracycline: mechanisms, transfer, and clinical significance. Clin Microbiol Rev 5, 387-399 (1992).

118. Mazel, D. Integrons: agents of bacterial evolution. Nat Rev Microbiol 4, 608-620, doi:10.1038/nrmicro1462 (2006).

119. Gaze, W. H. et al. Impacts of anthropogenic activity on the ecology of class 1 integrons and integron-associated genes in the environment. ISME J 5, 1253-1261, doi:10.1038/ismej.2011.15 (2011).

120. Liebert, C.A., Hall, R. M. \& Summers, A. O. Transposon Tn21, flagship of the floating genome. Microbiol Mol Biol Rev 63, 507-522 (1999).

121. Hall, J.P.J., Williams, D., Paterson, S., Harrison, E. \& Brockhurst, M.A. Positive selection inhibits gene mobilisation and transfer in soil bacterial communities. Nat Ecol Evol 1, 13481353. doi:10.1038/s41559-017-0250-3 (2017). 
122. Langille, M. G. I., Hsiao, W. W. L. \& Brinkman, F. S. L. Detecting genomic islands using bioinformatics approaches. Nat Rev Microbiol 8, 372-382, doi:10.1038/nrmicro2350 (2010).

123. San Millán, A., Escudero, J. A., Gifford, D. R., Mazel, D. \& MacLean, R. C. Multicopy plasmids potentiate the evolution of antibiotic resistance in bacteria. Nat Ecol Evol 1, 10, doi:10.1038/s41559-016-0010 (2017).

124. Maddamsetti, R. \& Lenski, R. E. Analysis of bacterial genomes from an evolution experiment with horizontal gene transfer shows that recombination can sometimes overwhelm selection. PLoS Genet 14, e1007199, doi:10.1371/journal.pgen.1007199 (2018).

125. Sakai, H. \& Komano, T. DNA replication of IncQ broad-hostrange plasmids in gram-negative bacteria. Biosci Biotechnol Biochem 60, 377-382, doi:10.1271/bbb.60.377 (1996).

126. Ojo, K. K. et al. Gram-positive merA gene in gram-negative oral and urine bacteria. FEMS Microbiol Lett 238, 411-416, doi:10.1016/j.femsle.2004.08.004 (2004).

127. Courvalin, P. Transfer of antibiotic resistance genes between gram-positive and gram-negative bacteria. Antimicrob Agents Chemother 38, 1447-1451, doi:10.1128/Aac.38.7.1447 (1994).

128. Klumper, U. et al. Broad host range plasmids can invade an unexpectedly diverse fraction of a soil bacterial community. ISME J 9, 934-945, doi:10.1038/ismej.2014.191 (2015).

129. Heinemann, J. A. \& Sprague, G. F. Bacterial conjugative plas- 
mids mobilize DNA transfer between bacteria and yeast. $\mathrm{Na}$ ture 340, 205-209, doi:10.1038/340205ao (1989).

130. Zhong, Z. P., Helinski, D. \& Toukdarian, A. Plasmid hostrange: restrictions to F replication in Pseudomonas. Plasmid 54, 48-56, doi:10.1016/j.plasmid.2004.11.001 (2005).

131. Schroder, G. \& Lanka, E. The mating pair formation system of conjugative plasmids-A versatile secretion machinery for transfer of proteins and DNA. Plasmid 54, 1-25, doi:10.1016/j. plasmid.2005.02.001 (2005).

132. Velappan, N., Sblattero, D., Chasteen, L., Pavlik, P. \& Bradbury, A. R. M. Plasmid incompatibility: more compatible than previously thought? Protein Eng Des Sel 20, 309-313, doi:10.1093/protein/gzmoo5 (2007).

133. Ebersbach, G. \& Gerdes, K. Plasmid segregation mechanisms. Annu Rev Genet 39, 453-479, doi:10.1146/annurev.genet.39.072902.091252(2005).

134. Nordstrom, K. \& Austin, S. J. Mechanisms that contribute to the stable segregation of plasmids. Annu Rev Genet 23, 37-69, doi:10.1146/annurev.ge.23.120189.000345 (1989).

135. Tuller, T. Codon bias, tRNA pools and horizontal gene transfer. Mob Genet Elements 1, 75-77, doi:10.4161/mge.1.1.15400 (2011).

136. Stalder, T. \& Top, E. Plasmid transfer in biofilms: a perspective on limitations and opportunities. NPJ Biofilms and Microbiomes 2, 16022, doi:10.1038/npjbiofilms.2016.22 (2016). 
137. Lopatkin, A. J. et al. Antibiotics as a selective driver for conjugation dynamics. Nat Microbiol 1, 16044, doi:10.1038/Nmicrobiol.2016.44 (2016).

138. Shoemaker, N. B. \& Salyers, A. A. Tetracycline-dependent appearance of plasmidlike forms in Bacteroides uniformis 0061 mediated by conjugal Bacteroides tetracycline resistance elements. J Bacteriol 170, 1651-1657 (1988).

139. Beaber, J. W., Hochhut, B. \& Waldor, M. K. SOS response promotes horizontal dissemination of antibiotic resistance genes. Nature 427, 72-74, doi:10.1038/natureo2241 (2004).

140. San Millán, A. \& MacLean, R. C. Fitness costs of plasmids: A limit to plasmid transmission. Microbiol Spectr 5, MTBP0016-2017, doi:10.1128/microbiolspec.MTBP-0016-2017 (2017).

141. Lopatkin, A. J. et al. Persistence and reversal of plasmid-mediated antibiotic resistance. NatCommun 8,1689, doi:10.1038/ S41467-017-01532-1 (2017).

142. Seiler, C. \& Berendonk, T. U. Heavy metal driven co-selection of antibiotic resistance in soil and water bodies impacted by agriculture and aquaculture. Front Microbiol 3, 399, doi:10.3389/fmicb.2012.00399 (2012).

143. Pal, C., Bengtsson-Palme, J., Kristiansson, E. \& Larsson, D. G. J. Co-occurrence of resistance genes to antibiotics, biocides and metals reveals novel insights into their co-selection potential. BMC Genomics 16, 964, doi:10.1186/s12864-015-2153-5 (2015). 
144. Harrison, E., Guymer, D., Spiers, A. J., Paterson, S. \& Brockhurst, M. A. Parallel compensatory evolution stabilizes plasmids across the parasitism-mutualism continuum. Curr Biol 25, 2034-2039, doi:10.1016/j.cub.2015.06.024 (2015).

145. Loftie-Eaton, W. et al. Compensatory mutations improve general permissiveness to antibiotic resistance plasmids. Nat Ecol Evol 1, 1354-1363, doi:10.1038/s41559-017-0243-2 (2017).

146. Harrison, E. et al. Rapid compensatory evolution promotes the survival of conjugative plasmids. Mob Genet Elements 6, e1179074, doi:10.1080/2159256X.2016.1179074 (2016).

147. Dahlberg, C. \& Chao, L. Amelioration of the cost of conjugative plasmid carriage in Eschericha coli K12. Genetics 165, $1641-1649$ (2003).

148. Amorós-Moya, D., Bedhomme, S., Hermann, M. \& Bravo, I. G. Evolution in regulatory regions rapidly compensates the cost of nonoptimal codon usage. Mol Biol Evol 27, 2141-2151, doi:10.1093/molbev/msq103 (2010).

149. Hall, J. P. J., Brockhurst, M. A., Dytham, C. \& Harrison, E. The evolution of plasmid stability: Are infectious transmission and compensatory evolution competing evolutionary trajectories? Plasmid 91, 90-95, doi:10.1016/j.plasmid.2017.04.003 (2017).

150. Hall, J. P., Wood, A. J., Harrison, E. \& Brockhurst, M. A. Source-sink plasmid transfer dynamics maintain gene mobility in soil bacterial communities. Proc Natl Acad Sci U S A 
113, 8260-8265, doi:10.1073/pnas.1600974113 (2016).

151. Mattila, S. et al. Conjugative ESBL plasmids differ in their potential to rescue susceptible bacteria via horizontal gene transfer in lethal antibiotic concentrations. J Antibiot (Tokyo) 70, 805-808, doi:10.1038/ja.2017.41 (2017).

152. Ojala, V. et al. Scoping the effectiveness and evolutionary obstacles in using plasmid-dependent phages to fight antibiotic resistance. Future Microbiol 11, 999-1009, doi:10.2217/ fmb-2016-0038 (2016).

153. Holcik, M. \& Iyer, V. N. A novel plasmid gene involved in bacteriophage PRD1 infection and conjugative host-range. Plasmid 35, 204-210, doi:10.1006/plas.1996.0022 (1996).

154. Tashiro, T. et al. Early trace of life from $3.95 \mathrm{Ga}$ sedimentary rocks in Labrador, Canada. Nature 549, 516-518, doi:10.1038/ nature24019 (2017).

155. Pedros-Alio, C. \& Manrubia, S. The vast unknown microbial biosphere.Proc Natl Acad Sci US A 113, 6585-6587, doi:10.1073/ pnas.1606105113(2016).

156. Whitman, W. B., Coleman, D. C. \& Wiebe, W. J. Prokaryotes: The unseen majority. Proc Natl Acad Sci U S A 95, 6578-6583, doi:10.1073/pnas.95.12.6578 (1998).

157. Editorial. Microbiology by numbers. Nat Rev Microbiol 9, 628-628, doi:10.1038/nrmicro2644 (2011).

158. Finlay, B. J. \& Esteban, G. F. Exploring Leeuwenhoek's legacy: the abundance and diversity of protozoa. Int Microbiol 4, 
125-133, doi:10.1007/s10123-001-0027-y (2001).

159. Methe, B. A. et al. A framework for human microbiome research. Nature 486, 215-221, doi:10.1038/nature11209 (2012).

160. Bakhshinejad, B. \& Ghiasvand, S. Bacteriophages in the human gut: Our fellow travelers throughout life and potential biomarkers of heath or disease. Virus Res 240, 47-55, doi:10.1016/j.virusres.2017.07.013 (2017).

161. Parfrey, L. W. et al. Communities of microbial eukaryotes in the mammalian gut within the context of environmental eukaryotic diversity. Front Microbiol 5, 298, doi:10.3389/ fmicb.2014.00298 (2014).

162. Hiltunen, T., Virta, M. \& Laine, A. L. Antibiotic resistance in the wild: an eco-evolutionary perspective. Philos Trans R Soc Lond B Biol Sci 372, 20160039, doi:10.1098/rstb.2016.0039 (2017).

163. Smillie, C.S. et al. Ecology drives a global network of gene exchange connecting the human microbiome. Nature 480, 241-244, doi:10.1038/nature10571 (2011).

164. Brito, I. L. et al. Mobile genes in the human microbiome are structured from global to individual scales. Nature 535, 435439, doi:10.1038/nature18927 (2016).

165. Spencer, S. J. et al. Massively parallel sequencing of single cells by epicPCR links functional genes with phylogenetic markers. ISME J 10, 427-436, doi:10.1038/ismej.2015.124 (2016). 
166. Bellanger, X., Guilloteau, H., Bonot, S. \& Merlin, C. Demonstrating plasmid-based horizontal gene transfer in complex environmental matrices: a practical approach for a critical review. Sci Total Environ 493, 872-882, doi:10.1016/j.scitotenv.2014.06.070 (2014).

167. Pfisterer, A. B. \& Schmid, B. Diversity-dependent production can decrease the stability of ecosystem functioning. Nature 416, 84-86, doi:10.1038/416084a (2002).

168. Wertz, S. et al. Decline of soil microbial diversity does not influence the resistance and resilience of key soil microbial functional groups following a model disturbance. Environ Microbiol 9, 2211-2219, doi:10.1111/j.1462-2920.2007.01335.x (2007).

169. Sommer, F., Anderson, J. M., Bharti, R., Raes, J. \& Rosenstiel, P. The resilience of the intestinal microbiota influences health and disease. Nat Rev Microbiol 15, 630-638, doi:10.1038/ nrmicro.2017.58 (2017).

170. Shade, A. et al. Fundamentals of microbial community resistance and resilience. Front Microbiol 3, 417, doi:10.3389/ fmicb.2012.00417 (2012).

171. Hautier, Y. et al. Local loss and spatial homogenization of plant diversity reduce ecosystem multifunctionality. Nat Ecol Evol 2, 50-56, doi:10.1038/s41559-017-0395-O (2018).

172. Trindade, S., Sousa, A. \& Gordo, I. Antibiotic resistance and stress in the light of Fisher's model. Evolution 66, 3815-3824, 
doi:10.1111/j.1558-5646.2012.01722.x (2012).

173. Hall, A. R. \& Corno, G. Tetracycline modifies competitive interactions in experimental microcosms containing bacteria isolated from freshwater. FEMS Microbiol Ecol 90, 168-174, doi:10.1111/1574-6941.12388 (2014).

174. Friman, V. P., Guzman, L. M., Reuman, D. C. \& Bell, T. Bacterial adaptation to sublethal antibiotic gradients can change the ecological properties of multitrophic microbial communities. Proc Biol Sci 282, 20142920, doi:10.1098/rspb.2014.2920 (2015).

175. Buckling, A. \& Rainey, P. B. Antagonistic coevolution between a bacterium and a bacteriophage. Proc Biol Sci 269, 931-936, doi:10.1098/rspb.2001.1945 (2002).

176. Hiltunen, T. \& Becks, L. Consumer co-evolution as an important component of the eco-evolutionary feedback. Nat Commun 5, 5226, doi:10.1038/Ncomms6226 (2014).

177. Allen, R. C., Pfrunder-Cardozo, K. R., Meinel, D., Egli, A. \& Hall, A. R. Associations among antibiotic and phage resistance phenotypes in natural and clinical Escherichia coli isolates. MBio 8, eo1341-17, doi:10.1128/mBio.01341-17 (2017).

178. Arias-Sánchez, F. I., Allen, R. C. \& Hall, A. R. Effects of prior exposure to antibiotics on bacterial adaptation to phages. $J$ Evol Biol, doi:10.1111/jeb.13220 (2017).

179. Knezevic, P., Curcin, S., Aleksic, V., Petrusic, M. \& Vlaski, L. Phage-antibiotic synergism: a possible approach to com- 
batting Pseudomonas aeruginosa. Res Microbiol 164, 55-60, doi:10.1016/j.resmic.2012.08.008 (2013).

180. Zhang, Q. G. Exposure to phages has little impact on the evolution of bacterial antibiotic resistance on drug concentration gradients. Evol Appl 7, 394-402, doi:10.1111/eva.12136 (2014).

181. Harrison, E. et al. Bacteriophages limit the existence conditions for conjugative plasmids. MBio 6, e00586 , doi:10.1128/ mBio.00586-15 (2015).

182. Matz C, K. S. Off the hook-how bacteria survive protozoan grazing. Trends Microbiol 13, 302-307, doi:10.1016/j. tim.2005.05.009 (2005).

183. Friman, V.P., Jousset, A. \& Buckling, A. Rapid prey evolution can alter the structure of predator-prey communities. J Evol Biol 27,374-380, doi:10.1111/jeb.12303 (2014).

184. Hiltunen, T., Gairns, J., Frickel, J., Jalasvuori, M., Laakso, J. Kaitala, V., Künzel, S., Karakoc, E. \& Becks, L. Multi-stressor selection alters eco-evolutionary dynamics in experimental communities. In review.

185. Davies, D. Understanding biofilm resistance to antibacterial agents. Nat Rev Drug Discov 2, 114-122, doi:10.1038/nrd1008 (2003).

186. Sørensen, S. J., Schyberg, T. \& Ronn, R. Predation by protozoa on Escherichia coli K12 in soil and transfer of resistance plasmid RP4 to indigenous bacteria in soil. Appl Soil Ecol 11, 
79-9o, doi:10.1016/So929-1393(98)00117-6 (1999).

187. Simek, K. et al. Morphological and compositional shifts in an experimental bacterial community influenced by protists with contrasting feeding modes. Appl Environ Microbiol 63, 587-595 (1997).

188. Wright, R. T. A model for short-term control of the bacterioplankton by substrate and grazing. Hydrobiologia 159, 111-117, doi:10.1007/Bfoooo7372 (1988).

189. Nair, J., Rouse, D. A., Bai, G. H. \& Morris, S. L. The rpsL gene and streptomycin resistance in single and multiple drug-resistant strains of Mycobacterium tuberculosis. Mol Microbiol 10, $521-527$ (1993).

190. Arias-Sánchez, F. I. \& Hall, A. R. Effects of antibiotic resistance alleles on bacterial evolutionary responses to viral parasites. Biol Letters 12, 20160064, doi:10.1098/rsbl.2016.0064 (2016).

191. Tazzyman, S. J. \& Hall, A. R. Lytic phages obscure the cost of antibiotic resistance in Escherichia coli. ISME J 9, 809-820, doi:10.1038/ismej.2014.176 (2015).

192. Zheng, Q. rSalvador: An R package for the fluctuation experiment. G3 (Bethesda) 7, 3849-3856, doi:10.1534/g3.117.300120 (2017).

193. Vogwill, T., Kojadinovic, M. \& MacLean, R. C. Epistasis between antibiotic resistance mutations and genetic background shape the fitness effect of resistance across species 
of Pseudomonas. Proc Biol Sci 283, 20160151, doi:10.1098/ rspb.2016.0151 (2016).

194. Hall, A. R., Scanlan, P. D., Morgan, A. D. \& Buckling, A. Host-parasite coevolutionary arms races give way to fluctuating selection. Ecol Lett 14, 635-642, doi:10.1111/j.14610248.2011.01624.x (2011).

195. Brockhurst, M. A., Morgan, A. D., Fenton, A. \& Buckling, A. Experimental coevolution with bacteria and phage. The Pseudomonas fluorescens-Ф2 model system. Infect Genet Evol 7,547-552, doi:10.1016/j.meegid.2006.01.005 (2007).

196. Zhang, Q. G. \& Buckling, A. Phages limit the evolution of bacterial antibiotic resistance in experimental microcosms. Evol Appl 5, 575-582, doi:10.1111/j.1752-4571.2011.00236.x (2012).

197. Bank, C., Ewing, G. B., Ferrer-Admettla, A., Foll, M. \& Jensen, J. D. Thinking too positive? Revisiting current methods of population genetic selection inference. Trends Genet 30 , 540-546, doi:10.1016/j.tig.2014.09.010 (2014).

198. Kotilainen, M. M., Grahn, A. M., Bamford, J. K. H. \& Bamford, D. H. Binding of an Escherichia coli double-stranded DNA virus PRD1 to a receptor coded by an IncP-type plasmid. J Bacteriol 175, 3089-3095 (1993).

199. Bien, T. L. T., Thao, N. V., Kitamura, S. I., Obayashi, Y. \& Suzuki, S. Release and constancy of an antibiotic resistance gene in seawater under grazing stress by ciliates and heterotrophic nanoflagellates. Microbes Environ 32, 174-179, doi:10.1264/ 
jsme2.ME17042 (2017).

200. Cairns, J., Koskinen, K., Penttinen, R., Patinen, T., Hartikainen, A., Jokela, R., Ruusulehto, L., Viitamäki, S., Mattila, S., Hiltunen, T. \& Jalasvuori, M. Black Queen evolution and trophic interactions determine plasmid survival after the disruption of conjugation network. In review.

201. Cooper, R. M., Tsimring, L. \& Hasty, J. Inter-species population dynamics enhance microbial horizontal gene transfer and spread of antibiotic resistance. Elife 6, e25950, doi:10.7554/eLife.25950 (2017). 